\title{
ROGAMUS TE, DOMINA NOSTRA - SZEŚĆ MODLITW MARYJNYCH ŚW. ANTONIEGO Z PADWY JAKO ŚWIADECTWO MARIOLOGII FRANCISZKAŃSKIEJ XIII WIEKU
}

Święty Antoni z Padwy jest jednym z najbardziej znanych świętych Kościoła katolickiego. W cieniu popularności tego cudotwórcy i patrona pozostają jego wielkie zasługi jako pierwszego znaczącego nauczyciela w zakonie franciszkańskim. Antoni jest nie tylko teologiem swojego czasu, ale również apostołem, mistrzem życia duchowego, wreszcie doktorem, świadkiem rozwoju teologii w tradycji augustiańskiej i franciszkańskiej.

„Św. Antoni był teologiem, był mistrzem, był doktorem scholastycznym, ale w scholastyce z początku XIII wieku". ${ }^{1}$ Na szczególne uznanie zasługuje jego dorobek kaznodziejski, którego spisanym świadectwem jest zbiór Sermones dominicales et festivi. ${ }^{2}$ Stanowi on osobny rodzaj literacki, charakterystyczny dla wczesnej scholastyki, a więc współczesny Antoniemu. Są to kazania uczone, w pewnym sensie homiletyczne traktaty, ${ }^{3}$ pisane przez świętego nie tylko w celu pokrzepienia

1 Por. C. N i e z g o d a, Św. Antoni Padewski, Warszawa 1984, s. 126 (dalej: SAP).

2 Wydanie krytyczne pism św. Antoniego: S. A n t o n i i P a t a vini, O. Min., Doctoris Evangelici, Sermones dominicales et festivi ad fidem codicum recogniti, t. I-III, Patavii 1979.

W dalszej części opracowania używane będą następujące skróty: I,150,23, gdzie cyfra rzymska oznacza tom wydania, kolejne zaś cyfry arabskie stronę i wers. W przypadku cytowania fragmentu modlitw maryjnych autor używa symboli $\mathrm{A}_{1}-\mathrm{B}_{2}$, przyporządkowujących cytat do danej części modlitwy (zestawienie treści kazań jako tabela w dodatku), zawsze jednak dodając w nawiasie odpowiednią lokację z wydania krytycznego Sermones.

3 Por. F. C o s t a, Sulla natura e la cronologia dei Sermoni di Sant'Antonio di Padova, Il Santo 39/1999, s. 36-37. 
dusz (consolatio), ale również przygotowania przyszłych kaznodziejów we franciszkańskiej wspólnocie (aedificatio). ${ }^{4}$ Doktor z Padwy nie był bowiem jedynie kaznodzieją, ale również nauczycielem ${ }^{5}$ i reformatorem kaznodziejstwa ${ }^{6}$ i to nie tylko na miarę swojej epoki. ${ }^{7}$

Działalność pisarska św. Antoniego odpowiada jego powołaniu przez samego św. Franciszka na pierwszego nauczyciela teologii w zakonie minorytów. ${ }^{8}$ Kazania Doktora Ewangelicznego, pełne treści biblijnej i życiowej mądrości, pisane były w myśl zasady: „Vivere santamente, per predicare pienament” (,Żyć święcie, aby głosić w pełni”). ${ }^{9}$ Reguła ta pozwala odkryć w kaznodziejstwie antoniańskim szkołę ${ }^{10} \mathrm{a}$ w samym Antonim mistrza i nauczyciela mod-

4 Por. V. Strapazzon, Introduction, w: Saint Antoine de Pad o u e. Docteur évangélique, Sermons des dimanches et des fêtes, t. 1, Padova 2005, s. XXXII: „Ils présentent donc une double caractéristique, pédagogique et pastorale: pédagogique dans la mesure où ils se réfèrent à l'enseignement dispensé par l'auteur aux Frères mineurs; pastorale en raison de la prédication tenue devant le peuple, et de l'enseignement destiné à l'administration des sacrements et à l'exercice de la prédication au peuple"; por. C. N i e z g o d a, Św. Antoni z Padwy. Życie i nauczanie, Kraków 2002, s. 161-162.

5 Por. B.J. U r b a n, Kazanie franciszkańskie - Słowo Boże XIII wieku, W Nurcie Franciszkańskim 1/1978, s. 304; R. M a n s e 11 i, S. Antonio di Padova e la prima predicazione francescana, Il Santo 8/1968, s. 18; S. C 1 a s e n, Lehrer des Evangeliums. Ausgewählte Texte aus den Predigten des hl. Antonius von Padua, Werl 1954, s. 27.

6 Por. A. P o m p e i, La predicazione di Sant'Antonio e i suoi contenuti, w: L. B e r t a z z o (red.), Antonio di Padova. Uomo evangelico. Contribuiti biografici e dottrinali, Padova 1995, s. 108-109; B.J. U r b a n, Św. Antoni Padewski jako kaznodzieja, w: Z. Kij a s, S.C. N a piórkowski (red.), Święty Antoni z Padwy. Mistrz w szkole franciszkańskiej, Kraków 1999, s. 144-145.

7 Por. A.F. F r i a s, Lettura ermeneutica dei „Sermones” di Sant'Antonio di Padova. Introduzione alle radici culturali del pensiero antoniano, Padova 1995, s. 95.

8 Por. Św. F r a n c i s z e k, Epistola ad Antonium, w: Pisma św. Franciszka z Asyżu. Teksty łacińskie i staro włoskie w polskim przekładzie, Kraków 2009, s. 414; komentarz do listu: tamże, s. 412-413; Źródła Franciszkańskie, Kraków 2005, s. 224; Św ięc i Francis ze k i K l a ra, Pisma, Kraków-Warszawa 2002, s. 59.

9 Por. A. P o m p e i, La predicazione di Sant'Antonio e i suoi contenuti, s. 113.

10 Por. A. B l a s u c c i, S. Antonio di Padova maestro di preghiera, Il Santo 2/1962, s.120. 
litwy. ${ }^{11}$ Nie dziwi więc fakt obecności wielu tekstów modlitewnych na kartach Sermones, których treść zależna jest od tematu danego kazania. Antoni zwraca się w nich do Ojca, Syna i Ducha Świętego, ale również do Maryi, ${ }^{12}$ używając przy tym różnych form: laudacji, prośby, dziękczynienia lub przebłagania. ${ }^{13}$

„Ze wszystkich kazań św. Antoniego najbardziej teologiczne są kazania o Matce Bożej". ${ }^{14}$ W pismach maryjnych Doktora Ewangelicznego znajduje się nie tylko jego kompletna mariologia, ${ }^{15}$ ale również świadectwo głębokiej łączności świętego z Matką Bożą, o czym świadczą spotykane modlitwy. ${ }^{16}$ Ich analiza wydaje się bardzo pożyteczna jako wstęp do pogłębionej refleksji nad mariologią Antoniego.

Myśl mariologiczna św. Antoniego, ,jest charakterystycznie tradycyjna, ale nie bez własnej świeżości, oryginalnych i genialnych pomysłów". ${ }^{17} \mathrm{~W}$ niniejszym rozważaniu przyjrzymy się sześciu wy-

1 Por. L. Polo n i a t o, Le preghiere dei Sermones di S. Antonio di Padova: contenuti teologici e spirituali, Padova 1989, s. 15; D.M. S p a r a c i o, S. Antonio di Padova. Taumaturgo francescano, nella vita, nel pensiero, nella gloria, t. 2, Padova 1923, s. 493-504; G. H e e r i n c k x, La mistica di s. Antonio di Padova, Studi Francescani 20/1933, s. 39-60.

12 Por. L. Pol o n i a t o, Le preghiere dei Sermones di S. Antonio di Padova, s. 17-23 (Interlocutori delle preghiere antoniane)

13 Por. tamże, s. 23-25 (Classificazione delle preghiere).

14 Por. SAP, s. 154.

15 Por. G.M. R o s c h i n i, La mariologia di s. Antonio di Padova, Marianum 8/1946, s. 20: „In tutti questi sermoni il S. Dottore ci fornisce elementi preziosi per costruire una Mariologia sostanzialmente completa“; „La Mariologia di S. Antonio ci si presenta con queste charatteristiche: sostanzialmente completa, ricca di sapore biblico, di immagini e di unzione"; tamże, s. 66.

16 Por. D.M. M o n $\mathrm{t}$ a g n a, Tracce di pietà mariana medievale nei ,,Sermones “ di Sant'Antonio, Il Santo 22/1982, s. 526; F.M. B a u d u c c o, Mariologia cherigmatica di S. Antonio di Padova, La civiltà cattolica 4/1952, s. 548.

17 Por. Dizionario di Mariologia, Roma 1961, s. 41, cyt. za: D.M. M o n t a g n a, Tracce di pietà mariana medievale nei ,, Sermones “ di Sant'Antonio, s. 521. Autorem tej opinii na temat mariologii antoniańskiej jest o. Roschini, autor jednego z pierwszych systematycznych opracowań tematu - por. G.M. R o s c h i n i, La mariologia di s. Antonio di Padova, s. 16-67. Autor innego opracowania, o. Lorenzo di Fonzo, 
branym modlitwom maryjnym, przedstawiając ich miejsce w kazaniach, następnie dokonamy analizy językowej i struktury ich tekstu, próbując dokonać syntezy zawartej w nich myśli mariologicznej Doktora z Padwy.

\section{Modlitwy jako część kazań maryjnych św. Antoniego}

Interesujące nas modlitwy nie są jedynymi fragmentami pism św. Antoniego, w których zwraca się on do Maryi. W zbiorze Sermones można znaleźć wiele miejsc, w których święty z Padwy porusza tematykę maryjną i mariologiczną. ${ }^{18}$ Nie brakuje tam również modlitw, które stanowią ważny element kaznodziejskiej myśli Doktora Ewangelicznego.

Kryterium wyboru analizowanych w niniejszym opracowaniu tekstów była zatem zawartość lingwistyczna i teologiczna, która pozwoliła na zestawienie i dokładną analizę wybranych modlitw. Charakterystyczną ich cechą jest początkowa inwokacja: „Rogamus te, Domina nostra". ${ }^{19} \mathrm{~W}$ tym świetle ze zbioru wszystkich modlitw antoniańskich, wyodrębniono sześć tekstów. Stanowią one zbiór oracji

nazywa naukę Antoniego mariologią swego czasu („Mariologia del tempo”); por. L. di F o n z o, La mariologia di S. Antonio, w: S. Antonio. Dottore della Chiesa. Atti delle settimane antoniane tenute a Roma e a Padova nel 1946, Città del Vaticano 1947, s. 89.

18 Por. J.V. G o n ç a lv e s, Glória de Maria à luz dos Sermões de Santo António, Itinerarium 171/2001, s. 430: „Além disso, em 32 dos 53 Sermões Dominicais há múltiplas referências a Virgem Maria”. Wśród wielu konkordancji tekstów Sermones na szczególne uznanie zasługują zestawienia dokonane przez badaczy mariologii antonińskiej; por. R. L a u r e n t i n, La Vierge Marie chez Saint Antoine de Padoue, Il Santo 22/1982, s. 518-519; D.M. M o n t a g n a, Repetitorio filologico, w: t e n ż e, Tracce di pietà mariana medievale nei ,, Sermones “ di Sant'Antonio, s. 529-533; J.V. G o n ç a lve s, Glória de Maria à luz dos Sermões de Santo António, s. 466-475.

19 Wyjątkiem jest pierwsza modlitwa z Kazania na Zwiastowanie NMP (6), w którym Antoni zamiast rogamus używa słowa supplicamus, o czym w dalszej części opracowania.Zestawienie modlitw Rogamus te znajduje się w opracowaniach mariologii antoniańskiej: por. D.M. M o n t a g n a, Le preghiere alla „,Domina nostra" nei sermoni mariani, w: t e n ż e, Tracce di pietà mariana medievale nei 
maryjnych, świadectwo głębokiej ufności i wiary we wstawienniczą modlitwę Dziewicy Matki.

\section{Źródła}

Modlitwy stanowią część pism maryjnych św. Antoniego z Padwy. Określenie „kazania maryjne” (sermones mariani) występuje w opracowaniach dotyczących źródeł antonińskich, ${ }^{20}$ zostało również przyjęte za tytuł II tomu wspomnianego wydania krytycznego pism Padewczyka: Sermones dominicales et festivi. Sermones dominicales et mariani. Właśnie w tym tomie kazań znajduje się znaczna ${ }^{21}$ część pism maryjnych Doktora Ewangelicznego: Cztery Kazania na święta Błogosławionej Dziewicy Maryi, ${ }^{22}$ zwane „małym Mariale

„,Sermones“ di Sant'Antonio, s. 533-535; J.V. G o n ç a 1 v e s, Glória de Maria à luz dos Sermões de Santo António, s. 441-443.

${ }^{20}$ Autorzy trzech klasycznych monografii dotyczących mariologii św. Antoniego (René Laurentain nazywa je podstawowymi opracowaniami mariologii antonińskiej; por. R. L a u r e n i n, La Vierge Marie chez Saint Antoine de Padoue, s. 491) używają określenia: „kazania maryjne” (łac. sermones mariani, wł. sermoni mariani); por. B. C o s t a, La mariologia di S. Antonio di Padova, Padova 1950, s. 24; L. di F on z o, La mariologia di S. Antonio, s. 91; G.M. R os c h i n i, La mariologia di s. Antonio di Padova, s. 20. W bibliografii antoniańskiej spotyka się również następujące określenia: „pisma maryjne” (scritti mariani) por. tamże, s. 20; „myśl maryjna” (il pensiero mariano) - por. L. G u i d a ld i, Il pensiero mariano di S. Antonio di Padova, Padova 1938, s. 6; Antonio di Padova, w: L. G a m b e ro (red.), Testi mariani del secondo millenio, Città Nuova 2012, s. 146; Mariale - por. J.V. G o n ç a lv e s, Glória de Maria à luz dos Sermões de Santo António, s. 430; D.M. M o n t a g n a, Le preghiere alla „Domina nostra” nei sermoni mariani, s. 522, 531; G.C. M o r a 1 e j o, Santa Maria en los Sermones de S. Antonio de Padua, Veridad y vida 53/1995, s. 331.

${ }_{21}$ Por. D.M. M o n t a $\mathrm{n}$ a, Le preghiere alla „Domina nostra” nei sermoni mariani, s. 522.

22 Ouattuor Sermones in Festivitatibus Beatae Virginis Mariae, w: II,101-150. W tym zbiorze znajdują się odpowiednio kazania: Na Narodzenie NMP (In Nativitate $B M V$ - dalej: In Nat), Na Zwiastowanie NMP (In Annuntiatione BMV-dalej: In Ann,) Na Oczyszczenie NMP (In Purificatione BMV - dalej: In Pur) i Na Wniebowzięcie NMP (In Assumptione BMV-dalej: In Ass). 
Antoniego". ${ }^{23}$ Pozostałe trzy kazania o tematyce maryjnej znajdują się odpowiednio w I ${ }^{24}$ oraz III $^{25}$ tomie Sermones.

Analizowane teksty modlitewne występują w wybranych kazaniach maryjnych. Stanowią ich integralną część, wieńcząc pojedynczą część lub całe kazanie. Taka kompozycja odpowiada zastosowaniu doksologii, która - jako ostatnia część - zamyka nie tylko poszczególną modlitwę, ale również całe kazanie.

Kolejność przedstawianych modlitw nie jest przypadkowa - odpowiada bowiem ich miejscu w wydaniu krytycznym pism Antoniego.

Pierwsza z modlitw, zatytułowana Rogamus ergo, Domina nostra, wieńczy kazanie wielkopostne Na chwałe Błogosławionej Maryi Dziewicy (In Laudem Beatae Mariae Virginis). ${ }^{26}$ Jest to niezależne kazanie maryjne w zbiorze kazań In Quadragesima, występujące bezpośrednio po Kazaniu na III Niedzielę Wielkopostna (Dominica III in Quadragesima). Zgodnie z tradycją badań nad tekstem kazań, tekst ten zaliczany jest do pism maryjnych Doktora Ewangelicznego.

Pozostałe modlitwy znajdują się w zbiorze Quattuor Sermones w II tomie wydania krytycznego pism antoniańskich. I tak: Rogamus ergo te, Domina nostra zamyka Kazanie na Narodzenie NMP (In Nativitate $B M V),{ }^{27}$ pierwsze z czterech „dużych” kazań maryjnych. Kolejne kazanie: Na Zwiastowanie NMP (In Annuntatione BMV) zawiera dwie modlitwy maryjne typu Rogamus te. Sama struktura tekstu kazania pozwala na wyodrębnienie trzech części, przy czym

${ }^{23}$ „Il piccolo mariale” - por. D.M. M o n t a g n a, Le preghiere alla „Domina nostra" nei sermoni mariani, s. 526.

24 Dominica III in Quadragesima. In Laudem Beatae Mariae Virginis, I,157-163 (dalej: IIIQuad L).

25 Są to dwa kazania w cyklu świątecznym (Sermones festivi): Na Święto Oczyszczenia NMP (In Festo Purificationis B. Mariae Virginis), III,99-117 (dalej: F Pur) oraz Na Zwiastowanie Świętej Maryi (In Annuntiatione Sanctae Mariae), III,151-168 (dalej: F Ann).

${ }^{26}$ IIIQuad L 7, I,163,3-9; por. D.M. M o n t a g n a, Le preghiere alla „Domina nostra" nei sermoni mariani, s. 523.

27 In Nat 4, II,108,6-14. 
pierwsza omawia cnoty i przywileje Maryi ${ }^{28}$ druga porównuje Syna Bożego do rosy, ${ }^{29}$ trzecia zaś koncentruje się na tajemnicy Narodzenia Pańskiego. ${ }^{30}$ Modlitwy maryjne zamykają odpowiednio pierwszą ${ }^{31}$ i trzecią ${ }^{32}$ część kazania. Tematyka poszczególnych części wyraźnie wpływa na kompozycję i zawartość wieńczących je oracji. Modlitwa, która zamyka kolejne kazanie: Na Oczyszczenie NMP (In Purificatione $B V M),{ }^{33}$ wieńczy jednocześnie jego trzecią część zatytułowaną: $O$ wielorakim ofiarowaniu Dziewicy. ${ }^{34} \mathrm{~W}$ kompozycji tej modlitwy zauważa się, podobnie jak w innych oracjach, liczne paralele do wcześniejszych treści Sermo. Ostatnie kazanie zbioru Quattuor Sermones: Na Wniebowzięcie NMP (In Assumptione BVM) zawiera szóstą modlitwę maryjną ${ }^{35}$ Wieńczy ona drugą część owego kazania noszącą tytuł: $O$ świętości i chwale błogosławionej Maryi Dziewicy. ${ }^{36}$

Powyższe zestawienie wykazało, że analizowane modlitwy maryjne stanowią element zamykający treść danej części wybranych pięciu kazań św. Antoniego. Wszystkie one należą do szeroko rozumianego zbioru pism maryjnych świętego z Padwy, które - jak już wspomniano - reprezentują jego całościowy wykład z dziedziny mariologii i duchowości maryjnej.

\section{Analiza językowa tekstu modlitw maryjnych}

Struktura językowa analizowanych modlitw antoniańskich charakteryzuje się niezwykłą konsekwencją i uporządkowaniem. W następującym rozważaniu zostaną porównane poszczególne części tej logicznej całości.

\footnotetext{
28 De virtutibus et praerogativis beatae Mariae Virginis, II,110,9-114,31.

29 De Filio Dei rori comparato, II,114,32-120,32.

30 De Nativitate Domini, II,121,1-126,30.

31 In Ann 6, II, 114,24-31.

32 Tamże, 16, II,126,23-30.

33 In Pur 9, II,140,22-28.

34 De multiplici oblatione Virginis, II,135,21-140,28.

35 In Ass 5, II,150,16-27.

36 De sanctitate et gloria beatae Mariae Virginis, II,144,10-150,27.
} 
Budowa modlitw Rogamus te... pozwala na wyodrębnienie dwóch podstawowych części. ${ }^{37} \mathrm{~W}$ pierwszej z nich Antoni zwraca się do Maryi, nadając Jej różne imiona i tytuły oraz przedstawiając konkretne prośby, które pasują do treści danego kazania. W drugiej części orant odnosi treści mariologiczne do Chrystusa, używa przy tym zmiennych konstrukcji językowych, wskazujących na tajemnicę święta, w związku z którym kazanie zostało napisane.

\section{Część inwokacyjna $\left(\mathrm{A}_{1}-\mathrm{A}_{2}\right)$}

Wszystkie modlitwy rozpoczynają się wezwaniem. Antoni zwraca się tu bezpośrednio do Maryi, kierując do Niej swoją prośbę. W części inwokacyjnej święty nie używa formy pojedynczej (rogo, supplico), ale mnogą (rogamus, supplicamus), wskazując przez to na wspólnotowość wezwania. ${ }^{38}$

Wobec konsekwentnego użycia słów ,prosimy Cię" (rogamus te) $)^{39}$ zauważono jeden wyjątek. W pierwszej modlitwie Kazania na Zwiastowanie NMP (In Ann 6) Antoni pomija słowo rogamus, stosując w tym miejscu wymiennie wyrażenie „prosimy Cię pokornie” (supplicamus tibi). ${ }^{40} \mathrm{~W}$ tym kazaniu pojawia się również wyjątkowo słowo eia ${ }^{41}$ będące swojego rodzaju wykrzyknikiem.

Obecne we wszystkich modlitwach słowo „zatem” $(\text { ergo })^{42}$ może wskazywać na łączność z treścią poprzednich części kazania, do których dana modlitwa nawiązuje. W tym świetle analizowane modlitwy maryjne stają się zwieńczeniem i zakończeniem wypowiedzi kaznodziei.

Elementem wspólnym dla wszystkich modlitw jest ich adresatka: Maryja, która konsekwentnie przyzywana jest charakterystycznym

37 W załączniku są to odpowiednio: część A i B.

38 Por. Introductio, w: S. A n t o n i i P a t a v i n i, O. Min., Doctoris Evangelici, Sermones dominicales et festivi, s. LV.

39 Por. A w: IIIQuad L 7, In Nat 4, In Ann 16, In Pur 9 oraz In Ass 5.

40 Por. $A_{1}$ w: In Ass 6 (II,114,24).

41 Por. tamże.

42 Por. $A_{1}$ we wszystkich modlitwach. 
dla średniowiecza ${ }^{43}$ tytułem: „,nasza Pani” (Domina nostra).${ }^{44}$ Rozwinięcie go jest związane z tematem modlitwy. Maryja nazwana została dwa razy nadzieją: „naszą nadzieją” (spes nostra) ${ }^{45}$ lub ,,jedyną nadzieją” (spes unica), ${ }^{46}$ jeden raz zaś ,gwiazdą zaranną” i „,księżycem w pełni” (stella matutina, plena luna) ${ }^{47}$,gwiazdą morza” (stella maris) ${ }^{48}$ „Boga Matką Karmicielką” (Dei mater alma), ${ }^{49}$ „Boga Matką wybraną" (Dei mater electa), ${ }^{50}$ jak również "sławną Matką Boga" (mater Dei inclita). ${ }^{51}$ Tytuły Maryi, następujące bezpośrednio po wezwaniu Domina nostra, nie mają zasadniczo dodatkowego rozwinięcia, wskazują jednak na rozważane święto i związane z nimi tajemnice zbawienia. Jedyny wyjątek stanowi tu dopowiedzenie do ostatniego tytułu mater Dei inclita, obecne w Kazaniu na Wniebowzięcie. Antoni uzupełnia go wzmianką o wywyższeniu Maryi ponad chóry anielskie: super choros angelorum exaltata. ${ }^{52}$

\section{Część rogacyjna, błagalna $\left(\mathrm{A}_{3}\right)$}

Po słowach wezwania i wyliczeniu tytułów maryjnych, następuje część błagalna modlitwy. Charakterystyczne dla niej jest konsekwentne użycie koniunktywów, które spotyka się we wszystkich analizowanych oracjach. Formy koniunktywne łączą się w logiczną całość

43 Por. D.M. Mo n t a g n a, Le preghiere alla „,Domina nostra” nei sermoni mariani, s. 525: „Antonio predilige, rispetto a «regina» l'elogio «Domina» (abitualmente nella forma tipica del basso medioevo «Domina nostra»). É la forma impiegata in tute le brevi preghiere conclusive dei vari sermones mariani di Antonio, su cui torneremo più inanzi. Siamo nel secolo (XII-XIII) di «notre Dame», non ancora della «madonna»".

44 Por. $\mathrm{A}_{2}$ we wszystkich modlitwach.

45 Por. $A_{2}$ w: IIIQuad L 7 (I,163,3).

46 Por. $A_{2}$ w: In Ann 6 (II,114,24).

47 Por. $\mathrm{A}_{2}$ w: In Nat 4 (II,108,6-7.9).

48 Por $\mathrm{A}_{2}$ w: IIIQuad L $7(\mathrm{I}, 163,4)$.

49 Por. $\mathrm{A}_{2}$ w: In Ann 16 (II,126,23).

50 Por $\mathrm{A}_{2} \mathrm{w}$ : In Pur 9 (II,140,22).

51 Por. $A_{2}$ w: In Ass 5 (II,150,16).

52 Por. $\mathrm{A}_{2} \mathrm{w}$ : tamże (II,150,17). 
z początkowym wezwaniem Rogamus te. Są one wprowadzane przez Antoniego za pomocą słowa ,aby” ( $u t)$ i wyrażają prośbę lub błaganie kaznodziei albo całego ludu. Padewczyk używa w pierwszym przypadku zawsze koniunktywu dla 2. osoby liczby pojedynczej, zwracając się w ten sposób bezpośrednio do Maryi. Zastosowanie zaś powtarzającej się w modlitwach formy dla 1. osoby: „abyśmy zasłużyli" (ut mereamur) ${ }^{53}$ wskazuje na życzenie samego autora, który - przez wspomniane już użycie liczby mnogiej - wypowiada się w imieniu swoich słuchaczy. Zastosowane czasowniki odpowiadają treści danego kazania i nawiązują do użytych w nim przykładów bądź figur. ${ }^{54}$

W modlitwie zamykającej Kazanie na chwałę Błogosławionej Maryi Dziewicy (IIIQuad L 7) występują następujące prośby do Maryi: „abyś oświeciła” (ut irradies), „doprowadziła” (ut dirigas), „obwarowała" (ut munias). Prośby te poprzedzają koniunktywy: „abyśmy bezpiecznie wyszli” oraz: ,abyśmy zasłużyli na dojście do szczęścia" (ut securi exire, ut ad gaudium pervenire meramur). ${ }^{55} \mathrm{Jak}$ wspomniano, Antoni łączy obydwa bezokoliczniki exire i pervenire $\mathrm{z}$ formą koniunktywną mereamur, wyrażając $\mathrm{w}$ ten sposób pragnienie słuchaczy kazania. Wyrażenie pervenire mereamur występuje dodatkowo we wszystkich modlitwach maryjnych z wyjątkiem Kazania na Wniebowzięcie NMP, dlatego jego wyliczanie zostanie pominięte w dalszej części niniejszego rozważania.

Modlitwa z Kazania na Narodzenie NMP (In Nat 4) wylicza następujące prośby: ,abyś rozpędziła” (ut expellas), ,abyś wypełniła” (ut adimpleas), ,abyś obmyła" (ut diluas). ${ }^{56}$

Dwie modlitwy maryjne, należące do Kazania na Zwiastowanie NMP (In Ann 6 oraz In Ann 16), ukazują następujące prośby: „abyś oświeciła” (ut illumines), ,abyś oczyściła” (ut emundes), ,abyś

53 1. pers. sing., praesens, conj. passiv od czasownika mereor, eri.

54 Łączność między modlitwami a treścią kazań zostanie omówiona w dalszej części niniejszego opracowania.

55 Por. $\mathrm{A}_{3}$ w: IIIQuad L 7 (I,163,4-7).

56 Por. $\mathrm{A}_{3}$ w: In Nat 4 (II,108,8-10). 
ogrzała” (ut calefacias), ,,abyś pojednała” (ut reconcilies $)^{57}$ oraz „abyś nam przebaczenie wyprosiła” (ut nobis indulgentiam impetres), „abyś uleczyła" (ut sanes) ${ }^{.58}$

Kolejna modlitwa maryjna z Kazania na Oczyszczenie NMP (In Pur 16) zawiera prośby: „abyś oczyściła” (ut purifices), ,abyś uczyniła" (ut facias)..$^{59}$

W ostatnim kazaniu Na Wniebowzięcie NMP funkcjonują następujące formy: „abyś wypełniła” (ut impleas), ,abyś uczyniła” (ut facias), „abyś umocniła” (ut consolides), „abyś ozdobiła” (ut adornes), „abyś wylała" (ut effundas), ,abyś zakryła" (ut operias). ${ }^{60}$ Zgodnie z powyższą zapowiedzią, w przypadku tego kazania słowo mereamur nie stoi w związku z wyrażeniem pervenire, lecz sublevari i beatificari. Ta konstrukcja wyraża pragnienie ,abyśmy zasłużyli na wyniesienie do niebieskiej chwały i byli szczęśliwymi ze świętymi” (qua ad caelestis gloriae altitudinem sublevari et cum beatis beatificari mereamur). ${ }^{61}$

\section{Część chrystologiczna $\left(\mathrm{B}_{1}\right)$}

Kolejna część, nazwana w niniejszym opracowaniu chrystologiczną, stanowi rozwinięcie myśli mariologicznej. Charakterystycznym wprowadzeniem jest forma ,za sprawą jego" (ipso praestante) ${ }^{62}$ po której Antoni rozwija własną myśl, dostosowując ją do tematyki danego święta. Jedynym wyjątkiem od tej reguły jest ponownie Kazanie na Wniebowzięcie NMP, w którym zamiast zaimka: ipso pojawia się bezpośrednie wezwanie Imienia Pańskiego: praestante Iesu Christo, ${ }^{63} \mathrm{~W}$ celu podkreślenia aktualności modlitwy oraz jej związku z celebrowanym świętem, Padewczyk używa słowa „dzisiaj” lub ,w dniu dzisiejszym” (hodie, hodierna die).

\footnotetext{
57 Por. $A_{3}$ w: In Ann 6 (II,114,25-27).

58 Por. $\mathrm{A}_{3} \mathrm{w}$ : tamże,16 (II,126,25-27).

59 Por. $\mathrm{A}_{3}$ w: In Pur 9 (II,140,23-25).

60 Por. $\mathrm{A}_{3}$ w: In Ass 5 (II,150,18-22).

${ }_{61}$ Por. $\mathrm{A}_{3} \mathrm{w}$ : tamże, 5 (II,150,22-23).

62 Por. $\mathrm{B}_{1} \mathrm{w}$ analizowanych modlitwach.

63 Por. $\mathrm{B}_{1}$ w: In Ass 5 (II,150,23).
} 
W analizowanej części Antoni zwraca się konsekwentnie do Maryi. Użyte formy czasownikowe odnoszą się więc bezpośrednio do Niewiasty (persona secunda) bądź Jej Syna (persona tertia). W ostatnim przypadku kaznodzieja łączy czasownik w 3. osobie z formą zaimka osobowego „ty” lub dzierżawczego „twój”, wskazując przez to na Maryję.

$\mathrm{Z}$ zestawienia poszczególnych modlitw wyłania się następujący obraz: ${ }^{64}$ „,nosiłaś” (portasti), „,karmiłaś” (lactasti) ${ }^{65}$, ,W Tobie stał się światłem” (in te lucem produxit), „sprawił, że się narodziłaś” (t e nascifecit), ${ }^{66}$ „z Ciebie zechciał wziąć ciało” (ex te carnem assumere voluit), ,zechciał zamieszkać w twoim łonie” (in t u o thalamo habitare voluit) $,{ }^{67}, \mathrm{z}$ Ciebie raczył się narodzić” (ex te nasci dignatus est) ${ }^{68}$, ,ofiarowałaś" (obtulisti), ${ }^{69}$ "Ciebie wyniósł ponad chóry aniołów" ( $t$ e super choros angelorum exaltavit), „Ciebie ukoronowat” (te coronavit), „Ciebie umieścit” (t e collocavit). ${ }^{70}$

\section{Doksologia $\left(\mathrm{B}_{2}\right)$}

Wszystkie modlitwy maryjne zakończone są doksologią: „Któremu jest cześć i chwała na wieki wieków. Amen" (Cui est honor et gloria per aeterna saecula. Amen.) Poszczególne doksologie zawierają nieznaczne różnice, chodzi zazwyczaj o pojedyncze słowa lub zmienioną kolejność słów. I tak wszystkie doksologie rozpoczynają się od „któremu” (cui), zaś w obydwu modlitwach z Kazania na Zwiastowanie NMP brakuje słowa ,jest” (est). ${ }^{71}$ Wspólne dla wszystkich części doksologicznych są słowa „chwała i cześć” (honor et gloria).

${ }^{64}$ Formy zaimkowe podkreślono w celu ukazania konsekwencji językowej św. Antoniego.

${ }^{65}$ Por. B 1 w: IIIQuad L 7 (II,163,8).

${ }^{66}$ Por. $\mathrm{B}_{1}$ w: In Nat 4 (II,108,12-13).

67 Por. B w: In Ann 6 (II,114,30).

${ }_{68}$ Por. $\mathrm{B}_{1} \mathrm{w}$ : tamze, 16 (II,126,29).

${ }_{69}$ Por. $B_{1}$ w: In Pur 9 (II,140,26-27).

70 Por. B w: In Ass 5 (II,150,24-25).

71 Por. $\mathrm{B}_{2}$ w: In Ann 6 i tamże 16. 
Wyrażenie „na wieki wieków” zostało oddane w trzech modlitwach przez łacińskie słowa per aeterna saecula, ${ }^{72} \mathrm{~W}$ pozostałych trzech występuje zaś: in saecula saeculorum. ${ }^{73} \mathrm{~W}$ oczywisty sposób doksologie zakończone są słowem „Amen”, które wieńczy każdą modlitwę maryjną św. Antoniego. Po raz kolejny wyjątek stanowi Kazanie na Wniebowzięcie NMP, w którym Padewczyk poszerza doksologię o wezwanie: „A cały Kościół niech powie: Amen. Alleluja” (Dicat omnis Ecclesia: Amen. Alleluia) ${ }^{74}$

\section{Szczegółowa analiza treści modlitw maryjnych św. Antoniego}

Analizowane modlitwy Rogamus te stanowią uzupełnienie i zwieńczenie treści poszczególnych kazań maryjnych św. Antoniego z Padwy. W tym świetle łatwiej jest zrozumieć ich zależność treściową od konkretnych wątków danego kazania. Następujące rozważanie ma na celu zestawienie zawartości teologicznej wszystkich modlitw.

We wszystkich modlitwach Maryja wzywana jest chwalebnym imieniem „Pani nasza” (Domina nostra).$^{75}$ Antoni używa takiego zestawienia słów w całym zbiorze swoich Kazań jedynie siedem razy, w tym sześć razy w formie wokatywnej - i są to właśnie wezwania w modlitwach maryjnych. ${ }^{76}$ Imię to jest uzupełniane o inne figury i obrazy maryjne, zmienne w zależności od treści danego kazania i celebrowanej liturgii.

72 Por. $\mathrm{B}_{2}$ w: In IIIQuad 7 (I,163,9); także w: In Ann 6 (II,114,31), In Ass 5 (II,150,26).

73 Por B , $_{2}$ In Nat 4 (II,108,14), In Ann 16 (II,126,30), In Pur 9 (II,140,27-28).

74 Por. $\mathrm{B}_{2}$ w: In Ass 5 (II,150,26-27).

75 Por $\mathrm{A}_{2}$ we wszystkich analizowanych modlitwach.

76 Forma niewokatywna występuje w kazaniu alegorycznym, będącym częścią Kazania na Święto Oczyszczenia Maryi Dziewicy (In Festo Purificationis Beatae Mariae Virginis); por. III,109,12-14: „Sic domina nostra, beata Maria, Dei Filium sine corruptione generavit, quoniam Spiritus Sanctus supervenit in ea, et virtus Altissimi obumbravit ei“. Należy zauważyć tu fakt użycia słowa domina pisanego od małej litery, co występuje w przypadku form wokatywnych, zawartych w modlitwach. 
Modlitwa z Kazania na III Niedzielę Wielkiego Postu - Na cześć Błogosławionej Maryi Dziewicy (Dominica III in Quadragesima. In Laudem BMV)

Pierwsza z analizowanych modlitw stanowi zakończenie Mowy na cześć Maryi. W wydaniu krytycznym Sermones dominicales et festivi znajduje się ona jako niezależny tekst, między Kazaniami na III i IV Niedzielę Wielkiego Postu, z racji samego tytułu przynależy jednak do III Niedzieli. ${ }^{77}$ Niektórzy tłumacze włączają ją nawet do tekstu kazania. ${ }^{78}$ Jak już wspomniano, przy okazji analizowania źródeł, mowa ta jest zaliczana do zbioru tekstów maryjnych św. Antoniego.

Modlitwa rozpoczyna się wezwaniem Maryi: „Pani nasza, nadziejo nasza" (Domina nostra, spes nostra).$^{79}$ Charakterystyczny jest tu podwójne użycie zaimka dzierżawczego nostra. Tego typu powtórzenie występuje jedynie w pierwszej modlitwie maryjnej. W kolejnym wersie modlitwy kaznodzieja przyzywa ponownie Maryję, używając przy tym tytułu „Gwiazda morza” (Stella maris). ${ }^{80}$ W pismach antoniańskich imię to występuje dziesięć, a w zbiorze pism maryjnych pięć razy ${ }^{81}$ i przysługuje wyłącznie Matce Bożej. ${ }^{82}$

77 I, 157-163.

78 Występuje to np. w tłumaczeniu na jęz. angielski, w którym zastosowano nawet ciągłą numerację paragrafów; por. S a int A n thony of $\mathrm{Padu}$ a. Doctor of the Church, Sermons for Sundays and Festivals, t. I, Padova 2007, s. 172-178. W tłumaczeniu włoskim mowa: In lode della Beata Vergine Maria jest traktowana jako V część poprzedzającego ją kazania wielkopostnego, z zachowaniem odrębnej numeracja paragrafów; por. S ant' Antonio di Padova, I Sermoni, Padova 2005, s. 151-155.

79 Por. $\mathrm{A}_{2}$ w: IIIQuad L 7 (I,163,3).

80 Por. $\mathrm{A}_{2}$ w: tamże $7(\mathrm{I}, 163,4)$.

81 IIIQuad L 7, I,163,4: (fragment analizowanej modlitwy); F Ann 3, III,153,7-9: „Quid est Maria, nisi m a r is s te 11 a, idest fluctuantibus in amaritudine ad portum clara via?”; F Ann 10, III,158,19-20: „Maria, id est m a r is st e 11 a, ipsius fidei confessione“; F Ann 14, III,162,23-26: „Nos vero dicimus: «Ave, Maria», id est $\mathrm{m}$ a r is stella, quia in medio maris sumus, fluctibus concutimur, tempestate submergimur, et ideo: S te 11 a $\mathrm{m}$ a r i s! clamamus, ut per ipsam ad portum salutis veniamus" (podkreślenia - N. S.).

82 Odpowiada to użyciu tego wezwania w liturgii Kościoła, o czym świadczy historia hymnu Ave Maris Stella; por. F. B a u m e is te r, Meerstern, 
Wraz z wezwaniem Gwiazdy morza Antoni formułuje trzy prośby, używając w nich liczby mnogiej. Jak już wspomniano, jest to wypowiedź nie tylko we własnym imieniu, ale również w imieniu wszystkich słuchaczy kazania. Wynika z tego konsekwentne zastosowanie form: nos, nobis, nostra, nostrum. Maryja, której samo imię w etymologii Antoniego oznacza gwiazdę. ${ }^{83}$ ma wskazać właściwą drogę: „Abyś nam, burzą tego morza wstrząśniętym, drogę oświeciła, do portu doprowadziła" (ut nobis huius maris tempestate concussis irradies, ad portum dirigas). ${ }^{84}$

Zastosowany w prośbie symbol burzy i portu odpowiada często spotykanym w Sermones figurom kaznodziejskim. Antoni ukazuje życie ludzkie jako rejs statku po niespokojnym morzu życia. W tym punkcie Padewczyk wpisuje się już w dawną tradycję katolickiej retoryki, sięgającą aż do św. Ambrożego ${ }^{85}$ Miotany falami i narażony na liczne niebezpieczeństwa statek życia znajduje się między dwoma brzegami, symbolizującymi dwa bieguny: śmiertelności i nieśmiertelności, pokusy świata i świętości życia, słowa i czynu. ${ }^{86}$ Celem tej podróży zaś jest port, czyli wieczność, odpoczynek, spełnienie. ${ }^{87}$ Wobec wielu zagrożeń tej ziemskiej podróży, pewnym drogowskazem i światłem jest, według Antoniego, przede wszystkim Gwiazda morza (Stella maris), czyli Maryja. Z kaznodziejskim zapałem woła on: „Maryja, czyli gwiazda morza, oto gwiazda, która wyprowadza z goryczy tego świata do portu wiecznego zbawienia". 88

w: R. Bä u mer, L. S c he ffc z y k (red.), Marienlexikon, t. 4, St. Ottilien 1992, s. 384.

${ }^{83}$ Por. M. W a g n e r, Da berühren sich Himmel und Erde. Symbol und Sakrament in den Sermones des Antonius von Padua, Kevelaer 2002, s. 272.

${ }^{84} \mathrm{~A}_{3}$ w: IIIQuad L 7 (I,163,3-4).

85 Por. A m brosiu s, Sermo 46,4,10, PL 17,720.

${ }^{86}$ Por. M. W a g n e r, Da berühren sich Himmel und Erde, s. 351.

87 Por. K. R a h n e r, Symbole der Kirche. Die Ekklesiologie der Väter, Salzburg 1964, s. 548-564.

${ }^{88}$ F Ann 10, III,158,19.22-23: „Maria, id est maris stella (...) ecce stella, duae ducit de saeculi amaritudine ad portum salutis aeternae". Wraz z użyciem alegorii: stella maris, Antoni podkreśla pokorę Maryi, która nie koncetruje się Predigten des Heiligen Antonius von Padua (Werl 1984), s. 94: „So setzt Antonius die Demut 
W tym świetle zrozumiała staje się kolejna prośba: „Abyś nasz koniec obwarowała opieką Twojej obecności" (exitum nostrum tuae praesentiae tutela munias). ${ }^{89}$ Analizowana modlitwa jest jedynym miejscem w kazaniach, w którym święty używa konstrukcji „twoja obecność" (tua praesentia). Dokładny dobór słów zdaje się wskazywać na intencję autora, aby jeszcze głębiej ukazać swoje zaufanie wobec wstawiennictwa Matki Bożej, Gwiazdy morza. Jej obecność w życiu człowieka jest postrzegana przez Antoniego jako gwarancja bezpiecznego przejścia z przemijalnego świata do wieczności. ${ }^{90}$ Wyrazem tego przekonania jest ostatnia z próśb pierwszej modlitwy maryjnej: „Abyśmy bezpiecznie wyszli z niewoli i z radością mogli dojść do nieskończonego szczęścia" (ut a carcere securi exire et ad gaudium infinibile laeti mereamur pervenire). ${ }^{91}$ Wszystkie trzy prośby pozostają zatem w konwencji drogi życia, wskazują na to występujące w nich słowa, użyte na oznaczenie wyjścia (exire), niebezpiecznej podróży (tempestas maris) i dojścia (pervenire, portus).

W drugiej części modlitwy Antoni wprowadza do swojej modlitwy chrystologiczny akcent: „Za sprawą tego, którego nosiłaś w błogosławionym łonie, najświętszymi piersiami karmiłaś" (Ipso praestante, quem beato ventre portasti, uberibus sacratissimis lactasti). ${ }^{92}$ Słowa te nawiązują do rozpoczynającego kazanie cytatu z Ewangelii wg św. Łukasza. ${ }^{93}$ Tematyka „błogosławionego łona” (beatus venter Mariae), które nosiło Jezusa pojawia się w 3 paragrafie Mowy na cześć Matki Bożej. ${ }^{94}$ Rozważanie o „błogosławionych piersiach” (ubera quae suxisti) wypełnia zaś paragraf 4 kazania. ${ }^{95}$

des Herzens gleichbedeutend den Meerestern, der die Nacht erleuchtet und zum sicheren Hafen geleitet".

${ }^{89} \mathrm{~A}_{3}$ w: IIIQuad L 7 (I,163,5-6).

90 Por. L. Polo n i t o, Le preghiere dei Sermones di S. Antonio di Padova, S. 105.

\footnotetext{
$91 \quad A_{3}$ w: IIIQuad L 7 (I,163,6-7).

92 B w: tamże (I,163,7-8).

93 Por. Łk 11,27 w: tamże, L 1, I,157,1-3.

94 Por. tamże, L 3, I,158,10-159,16.

95 Por. tamże, L 4, I,159,17-160,11.
} 
Analizowany tekst zostaje zamknięty doksologią: „Któremu cześć i chwała na wieki wieków" (Cui est honor et gloria per aeterna saecula) ${ }^{96}$ Następujące po niej słowo „Amen” wieńczy treść modlitwy i całego kazania.

\section{Modlitwa z Kazania na Narodzenie NMP (In Nativitate BMV)}

Kolejna modlitwa stanowi zwieńczenie Kazania na Narodzenie $N M P$, a konkretnie jego części zatytułowanej Zwiastowanie Maryi o Zbawicielu i Jej petna doskonatośc ${ }^{97}$ (De beata Maria Salvatoris nuntia et ex omni parte perfecta).${ }^{98}$ Maryja otrzymuje tu dwa imiona: „Gwiazda zaranna” (stella matutina) oraz „księżyc w pełni” (luna plena). ${ }^{99}$

W zbiorze Sermones wyrażenie stella matutina użyte zostało 15 razy, w tym 8 razy w zbiorze kazań maryjnych. ${ }^{100}$ Zgodnie z zapowiedzią, obecną w Prologu do Czterech Kazań Maryjnych, ${ }^{101}$ stella matutina należy do tematu pierwszego z kazań. Nie dziwi więc fakt, że imię to pojawia się dwa razy w Exordium, ${ }^{102}$ trzy razy

96 B w: IIIQuad L 7 (I,163,8-9).

97 Tłumaczenie za: SAP, s. 324.

98 In Nat 2-4, II, 106,1-108,14.

99 Por. $A_{2}$ w: In Nat 4 (II,108,6-7.8-9): „tu, quae es stella matutina (...) tu, quae es luna plena".

${ }^{100}$ Wszystkie dane statystyczne, dotyczące użycia poszczególnych słów w zbiorze Kazań św. Antoniego, pochodzą z elektronicznego wydania pism Antoniego: I Sermoni, wydawnictwa Edizioni Messaggero Padova w Padwie, ogólnie dostępnego w internecie - por. http://www.santantonio.org/portale/sermones/default.asp (dostęp: 29 XII 2015).

${ }_{101}$ Prologus in Quattuor Sermones in Festivitatibus Beatae Mariae Virginis, II, 104 (dalej: Prol).

102 Por. In Nat 1, II,105,5-6: „Dicamus ergo: Gloriosa Virgo Maria fuit quasi stella matutina” oraz In Nat 1, II,105,23-24: „Et ideo bene dicit Ecclesiasticus: Quasi stella matutina in medio nebulae etc". 
w paragrafie $2,{ }^{103}$ jeden raz w paragrafie $3^{104}$ oraz w paragrafie 4 , którego część stanowi modlitwa maryjna. ${ }^{105}$ Wszystkie miejsca odnoszą się do faktu narodzenia Maryi, jako przewodniego wątku całego kazania. Maryja, jako „najjaśniejsza gwiazda” (inter omnia sidera clarius luceat) ${ }^{106}$ rodzi się ,pośrodku mgieł” (in medio nebulae nata ${ }^{107}$ jako ,światło narodów” (lux populorum). ${ }^{108}$ Wobec takiego obrazu Maryi nie dziwi skierowana do Niej prośba: „Abyś swoim blaskiem rozpędziła mgłę szatańskiego podstępu, okrywającego świat naszego ducha”. ${ }^{109}$ "Ciemna mgła" (nebula tenebrosa), opary, to wspomniany wcześniej w kazaniu symbol zła. ${ }^{110}$ Ratunkiem jest „,blask” (splendor) Maryi, której narodzenie „rozpędza” (expellere) ${ }^{111}$ „,mgłę szatańskiego podszeptu" (nebulam daemoniacae suggestionis). ${ }^{112} \mathrm{Na}$ uwagę zasługuje fakt, że wyrażenie suggestio daemoniaca występuje w pismach św. Antoniego pięć razy, w pismach maryjnych pojawia się jednak jedynie raz $\mathrm{W}$ analizowanej modlitwie.

Drugie wezwanie Maryi: luna plena występuje w Sermones 20 razy. W Kazaniach maryjnych pojawia się ono 4 razy, zawsze w kontekście tajemnicy narodzenia Niewiasty. Wynika to z faktu

103 Por. In Nat 2, II,106,2-3: ,Stella matutina dicitur Lucifer, eo quod inter omnia sidera clarius luceat, quae proprie iubar dicitur“, In Nat 2, II,106,5-8: „Stella matutina sive Lucifer est beata Maria, quae, in medio nebulae nata, nebulam tenebrosam effugavit, mane gratiae solem iustitiae sedentibus in tenebris nuntiavit" oraz In Nat 2, II,106,21-22: „Fuit ergo beata Maria «quasi stella matutina» in sua Nativitate“.

${ }^{104}$ Por. In Nat 3, II,107,26-29: „Si haec triplex generatio in te praecesserit, quartam consequeris generationem, scilicet Iesu Christi, qui natus est de Virgine Maria, de cuius hodierna Nativitate dicitur: Quasi stella matutina in medio nebulae“.

${ }_{105}$ Por. A, w: In Nat 4 (II,108,6-7).

106 Por. In Nat 2, II,106,2-3.

${ }_{107}$ Por. tamże, II,106,8.

108 Por. tamie, II,106,12-13.

${ }^{109} \mathrm{~A}_{3}$ w: In Nat 4 (II,108,6-8): „Ut tu (...) nebulam daemonicae suggestionis, mentis nostrae terram tegentem, tuo splendore expellas".

110 Por. In Nat 2, II,106: „Maria, quae, in medio nebulae nata, nebulam tenebrosam effugavit, mane gratiae solem iustitiae sedentibus in tenebris nuntiavit".

111 Por. $\mathrm{A}_{3}$ w: In Nat 4 (II,108,8).

112 Por. $\mathrm{A}_{3} \mathrm{w}$ : tamże (II,108,7). 
przyporządkowania już w Prologu odpowiedniego cytatu z Mądrości Syracha do tematu Kazania na Narodzenie NMP: „Jako gwiazda zaranna między mgłami i jako pełny księżyc we dni swoje świeci". ${ }^{113}$ Obydwie figury astronomiczne: księżyca i gwiazdy, symbolizujące pełnię światła, ${ }^{114}$ mają ukazywać doskonałość cnót Maryi ${ }^{115} \mathrm{w}$ której nie ma żadnej skazy ani rogów. ${ }^{116}$ Przy okazji porównania księżyca w pełni z księżycem niepełnym, Antoni roztacza swoją wizję doskonałości Maryi, powołując się przy tym na wykład św. Bernarda: ${ }^{17}$ „Chwalebna Dziewica ani w swym narodzeniu nie posiadała plamy, została bowiem uświęcona w łonie matki, przez aniołów ustrzeżona, ani w swym życiu rogów pychy, i dlatego świeci pełna i doskonała. Zwana jest światłem, bo oczyszcza ciemności". ${ }^{118}$ Maryja, Niewiasta doskonała, jest zatem adresatem kolejnej prośby, ,[abyś] wypełniła naszą pustkę i obmyła ciemność naszych grzechów" (vacuitatem nostram adimpleas, peccatorum nostrorum tenebras diluas). ${ }^{119}$

Trzecia prośba, wyrażająca pragnienie wiernych, dotyczy dojścia do „pełni życia wiecznego” (ad vitae aeternae plenitudinem) oraz do ,'światła chwały nieskończonej” (ad gloriae indeficientis lucem). ${ }^{120}$

113 Por. Eccli 50,6 w: Prol, II,104,16-17: „Quasi stella matutina in medio nebulae, et quasi luna plena in diebus suis lucet".

114 Por. J. S c h n e i d e r, Mariologische Gedanken in den Predigten des Heiligen Antonius von Padua, Werl 1984, s. 70: „Die Gnadenfülle Marias ist die Fülle des Lichts. Schon bei ihrer Geburt wird sie als Morgenstern und Lichtträger bezeichnet, der so hell ist, dass er die Welt zu erleuchten vermag.“

115 Por. In Nat 4, II,107,31-108,1: „Beata Maria dicitur plena luna, quia ex omni parte perfecta".

116 Por. tamże, II,108,1: Luna ideo imperfecta et semiplena, quia habet maculam et cornua".

117 Por. B e r n a r d, In Assumptione B.M.V., sermo 2,8, PL 183,420; Epistola 174 (ad Canonicos Ludgunenses), 3-5, PL 132,1044.

118 In Nat 4, II,108,2-4: „Sed gloriosa Virgo nec in sua Nativitate habuit maculam, quia in utero matris fuit sanctificata, ab angelis custodita; nec in diebus suis cornua superbiae, et ideo plena et perfecta lucet. Lux dicta, quod diluat tenebras“. Tłumaczenie za: SAP, s. 326.

119 Por. $\mathrm{A}_{3}$ w: In Nat 4 (II,108,9-10).

${ }^{120}$ Por. $\mathrm{A}_{3} \mathrm{w}$ : tamże (II,108,11). 
Łączność między atrybutami Maryi (księżyc w pełni - gwiazda zaranna) a celem proszących (pełnia życia - światło chwały) ukazuje subtelność słowa Doktora Ewangelicznego i jego teologicznej myśli.

Modlitwa z Kazania na Narodzenie NMP zostaje zwieńczona krótką dygresją chrystologiczną, również nawiązującą do tematyki światła. To Syn Niewiasty, który w niej „stał się naszym światłem” (in te lucem nostram produxit), ${ }^{121}$ jest Gwarantem wypełnienia zanoszonych próśb. Chrystus, aby móc narodzić się z Maryi, sprawił narodzenie swej Matki, stawiając Ją na drodze historii zbawienia (qui ut ex te nasceretur, te hodie nasci fecit). ${ }^{122}$ Słowo „dzisiaj” (hodie), zastosowane tu w odniesieniu do narodzin Dziewicy, podkreśla łączność modlitwy z celebracją liturgiczną i aktualność kontemplowanej tajemnicy. Ostatnimi słowami analizowanego tekstu jest doksologia: cui est honor et gloria in saecula saeculorum. ${ }^{123}$

Pierwsza modlitwa z Kazania na Zwiastowanie NMP (In Annuntiatione BMV)

Modlitwa ta kończy pierwszą część kazania, zatytułowaną $O$ cnotach i przywilejach błogosławionej Maryi Dziewicy (De virtutibus et praerogativis beatae Mariae Virginis). ${ }^{124}$ Rozpoczyna się ona wykrzyknikiem eia ergo, po nim Maryja zostaje wezwana figuratywnym imieniem „nasza nadzieja” (spes unica). ${ }^{125}$ Słowo spes jest częste u św. Antoniego (występuje bowiem 54 razy w Sermones), w tym zestawieniu spotykane jest jednak tylko raz $\mathrm{w}$ analizowanej modlitwie. Maryja, nadzieja nasza, jest proszona pokornie (supplicamus tibi) o łaskę dla naszych dusz (mentes nostras). Podobnie jak i w poprzednich modlitwach, Antoni wypowiada się w imieniu większej grupy ludzi, zapewne słuchaczy i odbiorców jego kazania, dlatego konse-

\footnotetext{
${ }^{121}$ Por. $\mathrm{B}_{1} \mathrm{w}$ : tamie (II,108,12).

${ }_{122}$ Por. $\mathrm{B}_{1} \mathrm{w}$ : tamie (II,108,13).

${ }^{123} \mathrm{~B}_{2} \mathrm{w}$ : tamże (II,108,13-14).

124 In Nat 2-6, II,110,9-114,31.

125 Por. A 2 w: In Ann 6 (II,114,24).
} 
kwentnie stosowane są formy liczby mnogiej (nos - nostra). Forma pokornej, uniżonej prośby, supplicamus tibi, jest obecna w Kazaniach Antoniego w dwóch miejscach: w Kazaniu na X Niedzielę po Pięćdziesiatnicy ${ }^{126} \mathrm{i}$ w kazaniu analizowanym obecnie. Obydwa miejsca stanowią fragment modlitw kończących część tematyczną danego Sermo, w pierwszym przypadku Antoni zwraca się do Trójcy Świętej (Supplicamus ergo tibi, Trinitas et Unitas), w drugim zaś do Dziewicy Maryi (Eia ergo, Domina nostra, supplicamus tibi).

Dary, o które proszona jest Maryja to: oświecenie światłem jej łaski (ut mentes nostras splendore tuae gratiae illumines), oczyszczenie jasnością jej czystości (candore tuae munditiae emundes), ogrzanie ciepłem jej nawiedzenia (calore tuae visitationes calefacias), wreszcie pojednanie z jej Synem (filio tuo nos reconcilies). ${ }^{127}$ Ten stan jedności z Bogiem ma doprowadzić proszących do blasku Jego chwały (ad ipsius gloriae splendorem pervenire mereamur). ${ }^{128}$ Prośby, zawarte $\mathrm{w}$ analizowanej modlitwie, korespondują z treścią pierwszej części Kazania na Zwiastowanie. W tajemnicy zwiastowania anielskiego Maryja została porównana do ,jaśniejącego słońca” (sol refulgens). ${ }^{129} \mathrm{~W}$ odniesieniu do trzech słów, wypowiadanych do Maryi przez anioła, Antoni wyprowadza triadę trzech wartości, opisujących słońce, a przez nie samą Niewiastę. ${ }^{130}$ I tak w słońcu znajdują się ,„światło” (splendor), ,jasność” (candor) i „ciepło” (calor).

${ }^{126}$ Por. Dominica X post Pentecosten, 11, II,47: „Supplicamus ergo tibi, Trinitas et Unitas, ut cum venerint dies afflictionis et ultimae incinerationis et ruptio argentei funis, anima, quam fecisti, ad te recurrat, tu eam suscipias, quatenus, ab obsidione daemonum liberata, in libertatem gloriae filiorum Dei mereatur advolare“.

${ }^{127}$ Wszystkie prośby są zawarte w A $\mathrm{A}_{3}$ w: In Ann 6 (II,114,25-27).

${ }^{128} \mathrm{~A}_{3} \mathrm{w}$ : tamże (II,114,27-28).

${ }^{129}$ Por. In Ann 2 (II,110,10-11): „Nota quod, beata Maria fuit quasi sol refulgens in Angeli Annuntiatione..."

${ }^{130}$ Por. J. S c h n e i d e r, Mariologische Gedanken, s. 71: „Die Worte des Engels sind mehr als nur Bezeichunungen oder Feststellungen; sie sind Namen, die das Wesen dieser Frau auszusprechen versuchen. Ihr Wesen aber kommt des Lichtes nahe". 
Kaznodzieja z Padwy przyporządkowuje je trzem częściom pozdrowienia anielskiego Maryi. ${ }^{131}$

Światło (splendor) Maryi wyraża się, w opinii Doktora Ewangelicznego, w jej czterech cnotach $^{132}$ i dwunastu prerogatywach (przywilejach). ${ }^{133}$ Autor, powołując się na wykład św. Bernarda, ${ }^{134}$ wylicza tu $\mathrm{z}$ wielką dokładnością i konsekwencją przywileje nieba (praerogativae caeli), ${ }^{135}$ ciała (praerogative carnis) ${ }^{136}$ i serca (praerogativae cordis). ${ }^{137}$ Jasność (candor) Niewiasty opisana jest za pomocą obrazu łona $\mathrm{z}$ kości słoniowej (venter eburneus) ${ }_{1}^{138} \mathrm{w}$ którym w jasności ducha (in candore mentis) i chłodzie ciała (in frigiditate corporis) ${ }^{139}$ nastąpiło wcielenie Słowa Bożego. Ciepło (calor) symbolizuje pokarm i pożywienie istot żywych. ${ }^{140}$ Nadejście prawdziwego ciepła (adveniente vero calore), ${ }^{141}$ będące następstwem zstąpienia Ducha Świętego (superveniente Spiritu Sancto), ${ }^{142}$ utożsamione zostało $\mathrm{z}$ poczęciem i wydaniem owocu przez ziemię błogosławioną (terra benedicta concepit et parturivit fructum benedictum). ${ }^{143}$

131 Por. In Ann 2 (II,110,12-14): „In sole sunt tria, scilicet splendor, candor et calor, quae tribus Gabrielis verborum clausulis respondent. Prima: Ave, gratia plena; secunda: Ne timeas; tertia: Spiritus Sanctus superveniet in te“.

${ }^{132}$ Por. tamże (II,110,18-19): „Potest hoc referri ad quattuor virtutes...”

133 Por. tamże (II,110,32-111,1): ,...duodecim praerogativas in Virgine dicit: quattuor praerogativias caeli, quattuor carnis, quattuor cordis fluxerunt quasi stellae de caelo".

${ }^{134}$ Por. B e r $\mathrm{n}$ h a r d, In Dominica infra octavam Assumptionis B.M.V., 7, PL 183,432-433.

135 Por. In Ann 2 (II,111,2-4).

136 Por. tamże (II,111,4-7).

137 Por. tami̇e (II,111,7-9).

${ }_{138}$ Por. In Ann 3 (II,111,17-18).

139 Por. tamże (II,111,19-20).

140 Por. In Ann 5 (II,113,2-3): „Nota quod calor est cibus et nutrimentum omnium viventium".

${ }^{141}$ Por. tamże (II,113,22-23).

142 Por. tamie (II,113,24).

143 Por. tamże (II,113,24-25). 
Z powyższej analizy wynika następujące zestawienie cech słońca, słów anioła i przywilejów Dziewicy:

1) Witaj, pełna łaski: światło słońca - oświecenie (Ave, gratia plena: splendor-illuminatio),

2) Nie lękaj się: jasność - oczyszczenie (Ne timeas: cador-munditio),

3) Duch Święty osłoni cię: ciepło - nadejście, nawiedzenie (Spiritus Sanctus superveniat in te - calor - adventus, visitatio)

W kontekście tego dokładnego wykładu o cnotach Maryi nie dziwi zawarta w kończącej modlitwie prośba do Niej o oświecenie dusz „światłem jej łaski” (splendore tuae gratiae illumines) ${ }^{144}$, oczyszczenie ich jasnością jej czystości (candore tuae munditiae emundes), wreszcie ogrzanie ciepłem nawiedzenia (calore tuae visitationes calefacias). Taka redakcja konkretnych próśb do Maryi ukazuje niezwykłą konsekwencję kompozycji św. Antoniego z Padwy.

Temat zwiastowania powraca również w drugiej części modlitwy. Doktor Ewangeliczny, aktualizując tajemnicę dnia za pomocą słów „W dniu dzisiejszym” (hodierna die), przytacza konsekwencje tego wydarzenia. Przez zwiastowanie anielskie (Angelo nuntiante) Chrystus zechciał przyjąć z Maryi chwalebne ciało i zamieszkać w Jej łonie przez dziewięć miesięcy (ex te gloriosam carnem assumere et in tuo thalamo novem mensibus voluit habitare) ${ }^{145}$ Użyte tu, pochodzące z języka greckiego, słowo thalamus, oznaczające ,pomieszczenie wewnątrz domu”, ${ }^{146}$ w obecnym kontekście zaś „łono” Maryi, znajduje częste zastosowanie w pismach maryjnych Antoniego. W Exordium Kazania na Zwiastowanie Maryja została nazwana mieszkaniem Syna Bożego (thalamus Filii Dei), w dalszej części tego kazania słowo thalamus pojawia się jeszcze dwa raz ${ }^{147}$, zawsze w bezpośred-

${ }^{144}$ Słowo splendor występuje jeszcze raz w zakończeniu części rogatywnej, tym razem w odniesieniu do Chrystusa: „Qua ad ipsius gloriae splendorem pervenire meream"; por. $A_{3}$ w: In Ann 6 (II,114,27-28).

145 Por. B w: tamże (II,114,29-30)

146 Por. Thalamus, w: M. P l e z i a (red.), Stownik tacińsko-polski, Warszawa 2007, t. 5 , s. 375 .

${ }^{147}$ Por. In Ann 3, II,18-21: „Ebur, os elephantis, est candidum et frigidum, in quo duplex munditia designatur: in candore mentis, in frigiditate corporis; quae duo 
niej łączności z osobą Niewiasty. Doksologia: cui honor et gloria per aeterna saecula ${ }^{148}$ zamyka trzecią modlitwę maryjną. Jest ona identyczna z doksologią modlitwy z Kazania Wielkopostnego. ${ }^{149}$

\section{Druga modlitwa z Kazania na Zwiastowanie NMP (In Annuntiatione BMV)}

Część III kazania jest zatytułowana O Narodzeniu Pańskim (De Nativitate Domini) ${ }^{150}$ Jej zwieńczenie stanowi kolejna modlitwa maryjna, w której św. Antoni podejmuje po raz kolejny wątek wcielenia Słowa Bożego i narodzenia Syna Bożego. Modlitwa jest kontynuacją myśli kaznodziei. Wskazuje na to partykuła „zatem” (ergo). ${ }^{151}$ Niewiasta otrzymuje chwalebne imię „Bożej Matki Karmicielki” (Dei mater alma) ${ }^{152}$ które w pismach św. Antoniego występuje tylko jeden raz. Imię to nawiązuje w swej wymowie do tradycji maryjnej antyfony Ave maris stella, co do której można przypuszczać, że była ona znana św. Antoniemu i środowisku trzynastowiecznych zakonów. ${ }^{153}$ Wezwanie Matki Karmicielki koresponduje z tajemnicą narodzenia Pańskiego (in hac nativitate filii tui), ${ }^{154}$ czego wyrazem są kolejne obrazy opisujące postać Maryi w świetle tego wydarzenia: „...którego jako Dziewica porodziłaś, owinęłaś w pieluszki, położyłaś w żłobie" (quem virgo peperisti, pannis involvisti, in praesepio

fuerunt in th a l a m o gloriosae Virginis“ (podkreślenie N.S.). Drugie miejsce to fragment analizowanej modlitwy (B, In Ann 6).

${ }_{148}$ Por. B $\mathrm{B}_{2}$ : In Ann 6 (II,114,30-31).

149 Por. B w: IIIQuad L 7 (I,163,8-9).

${ }^{150}$ In Ann 12-16,(II,121,1-126,30).

151 Por. A w: In Ann 16 (II,126,23).

${ }_{152}$ Por. $\mathrm{A}_{2}$ w: tamże (II,126,23).

153 Antyfona Ave maris stella była popularna już w średniowieczu, o czym świadczą liczne kompozycje z tego okresu. Za autora tekstu uważani byli: Bernard z Clairvaux (XII w.), Wenancjusz Fortunat (VI w.) czy Herman z Reichenau (XI w.). Najstarszy manuskrypt, zawierający tekst antyfony, znajduje się w opactwie w Sankt Gallen i pochodzi z IX w.; por. G. B e m t, Ave maris stella, w: R. B ä u m e r, L. S cheffc z y k (red.), Marienlexikon, s. 317.

${ }^{154}$ Por. $A_{2}$ w: In Ann 16 (II,126,23-24). 
reclinasti). ${ }^{155}$ Antoni kontempluje tu misterium Dziewicy Matki, podkreślając słowami: „,dziewica” (virgo) i ,porodziłaś” (peperisti) niezwykłość powołania Maryi. Podobne myśli pojawiają się już we wcześniejszym fragmencie analizowanego kazania, w którym poród Najświętszej Dziewicy przyrównano do róży i lilii, „ponieważ ich kwiat nie niszczeje, pomimo że wydają najprzyjemniejszą woń. Tak Najświętsza Maryja, pomimo że porodziła Syna Bożego, nadal pozostała Dziewicą". ${ }^{156}$ Obraz Syna Bożego owiniętego w pieluszki ${ }^{157}$ i leżącego w żłobie ${ }^{158}$ został zaczerpnięty z Ewangelii Łukaszowej, ${ }^{159}$ konsekwentnie cytowanej i omawianej w kazaniu przez Padewczyka. Żłób (praesepium) oraz pieluszki (pannis) stanowią w alegorii antonińskiej symbol pokory, wstrzemięźliwości i ubóstwa ${ }^{160}$ i są znakiem uniżenia się Słowa Bożego, które stało się Ciałem. ${ }^{161}$

Następujące w dalszej części modlitwy prośby nawiązują w swej wymowie również do treści kończącego się kazania. Maryja jest proszona o wyproszenie u swego Syna daru przebaczenia (indulgentiam nobis ab ipso impetres) ${ }^{162}$ oraz uleczenia plastrem swego miłosierdzia oparzeń duszy, doznanych na skutek ognia grzechu (adustionem ani-

${ }^{155}$ Por. tamże (II,126,24-25). D.M. Montagna widzi w tym miejscu modlitwy rytmiczny fragment wskazujący na możliwą proweniencję hymniczną; por. D.M. M o n t a g n a, Le preghiere alla „Domina nostra” nei sermoni mariani, s. 525: „Una movenza di inno (rimato, per giunta) ha un frammento di preghiera contenuto nel sermone In annuntiatione beatae Mariae virginis..."

${ }^{156}$ In Ann 13 (II,121,19-22): „Gloriosae Virginis partus rosae et lilio comparatur, quia sicut ista suavissimum spirando odorem, eorum flos non corrumpitur, sic beata Maria, Dei Filium parturiendo, Virgo permansit". Cyt. za: G u e r i c u s A b b a s, In Nativit. b. M. sermo 1,3, PL 185,201, por. II,121, przyp. 98. Tłumaczenie za: SAP, s. 336.

157 Por. In Ann 14 (II,123,31): „Invenietis inquit, pannis involutum”.

${ }_{158}$ Por. tamże (II,123,24): „Sequitur: Positum in praesepio”.

${ }_{159}$ Por. In Ann 13 (II,122,25-29), gdzie cytowany jest Łk 2,10-12.

${ }^{160}$ Por. In Ann 14 (II,122,33-123,3): „Hoc vobis signum, quo vos consignetis; invenietis infantem, «ecce hu milit as »; positum in praesepio, non ad ubera matris, ecce abstinentia; pannis involutum, ecce p a u p r t a s “ (podkreślenia N. S.).

${ }_{161}$ Por. In Nat 14, II,123,24-124,21.

162 Por. $A_{3}$ w: In Ann 16 (II,126,25-26). 
mae nostrae, quam ex igne peccati contraximus, tuae misericordiae emplastro sanes). ${ }^{163}$ Słowo ,przebaczenie” (indulgentia), występujące w tym miejscu, nie znajduje żadnych powtórzeń w innych pismach maryjnych Antoniego. Inaczej jest w przypadku słowa „wypraszać” (impetrare), którego Padewczyk używa częściej w swoich pismach, utożsamiając je $\mathrm{z}$ wytrwałym wołaniem do Boga. ${ }^{164} \mathrm{~W}$ kontekście specyfiki języka św. Antoniego pierwsza prośba może więc zawierać wyobrażenie stałej modlitwy Dziewicy Matki za swoje dzieci. Wyrażenie „stałość modlitwy” (orationis instantia) ${ }^{165}$ pojawia się w kazaniu właśnie w odniesieniu do Maryi, jako jeden z przymiotów alegorycznego obrazu „róży we dni wiosenne i lilii rosnących nad płynącą wodą”. ${ }^{166}$

Druga z próśb do Maryi nawiązuje bezpośrednio do symboli obecnych w kazaniu. We fragmencie bezpośrednio poprzedzającym modlitwę maryjną, Antoni, cytując Izydora z Sewilii, ${ }^{167}$ roztacza wizję postawionego na ogniu garnka $\mathrm{z}$ bulgoczącą wrzącą wodą, z którego unosi się para. ${ }^{168}$ Garnek symbolizuje w nauczaniu moralnym Padewczyka ducha grzesznika, w którym gotuje się woda pożądliwości (aqua concupiscentiae), buchając parą przewrotnych myśli. Dym zaciemnia oblicze duszy, a duch grzesznika brudzi się czernią grzechu (et sic nigredinem contrahit mens peccatoris). ${ }^{169}$ Ratunkiem na ten

163 Por. tami̇e (II,126,26-27).

164 Por. Dominica VI post Pascha, 8, I,362,15-17: „Et si ita solus remanserit, bene cum Domino luctari poterit et i m p e t r a r e ab eo quod voluerit, et audire merebitur...“; Dominica XIV post Pentecosten, II,211, 20-22: „Quicumque istiusmodi leprae quinquepartito genere fuerit maculatus, si a Domino vult misericordiam i m p e $t \mathrm{r}$ a $\mathrm{r}$ e, oportet eum quinque supradicta agere" (podkreślenia N. S.).

${ }^{165}$ Por. In Ann 12, (II,121,7-8): „In hac auctoritate tria notantur, scilicet lacrimarum abundantia, orationis instantia et vitae munditia”.

${ }^{166}$ Por. tamże (II,121,2-3): „Quasi flos rosarum in diebus vernis, et quasi lilia quae sunt in transitu aquae”. Cytowany tu Syr 50,8 jest tematem całej części „,De Nativitate Domini" Kazania na Zwiastowanie NMP.

167 Por. I s i d o r, Etym. XX,8,2, PL 82,718, cyt. za II,126, przyp. 139.

168 Por. In Ann 16 (II,126,6-8): „Olla est vas ad coquendum, 'dicta quod debuliat in ea aqua, igne subiecto, et vapor emittatur. Unde et bulla dicitur, quae in aqua venti spirituintus sustentatur'“.

169 Por. tamie (II,126,8-13). 
stan jest Dziewica Matka. Antoni wyznaje: „Ten brud i oparzenie usuwa Najświętsza Maryja leczniczym pięknem swej świętości, oraz udziela doskonałej świętości tym, którzy jej ufają." ${ }^{170}$ Następująca po tym wyznaniu modlitwa potwierdza ufność Doktora Ewangelicznego w skuteczność wstawienniczej modlitwy Matki, która leczy plastrem swego miłosierdzia (misericordiae emplastro) oparzenia duszy. Antoni często używa słowa „miłosierdzie” (misericordia), a w analizowanym kazaniu odnosi ten przymiot bezpośrednio do osoby Maryi, nazywając ją wprost „olejem miłosierdzia” (est enim oliva misericordiae), ${ }^{171}$ a jej działanie leczącym ,plastrem" (emplastro). Wyproszenie przebaczenia i uleczenie ran przez Niewiastę ma w końcu doprowadzić słuchaczy kazania do radości wiecznego święta (ad aeternae festivitatis gaudium) ${ }^{172}$

W drugiej części modlitwy powraca krótko temat narodzenia Pańskiego. Antoni, używając sprawdzonej już aktualizacji „dzisiaj” (hodie), wspomina ponownie tajemnicę dnia: „...za sprawą tego, który z Ciebie, chwalebnej Dziewicy, raczył się dziś narodzić" (ipso praestante, qui ex te, gloriosa Virgine, hodie nasci dignatus est).$^{173}$ Nadanie Maryi imienia „chwalebna Dziewica” (Virgo gloriosa) występuje 18 razy w pismach maryjnych Padewczyka. Analizowana modlitwa jest jednak jedynym miejscem, w którym autor używa dodatkowo przyimka ex (,,z"), podkreślając przez to fakt narodzenia Syna z Niewiasty. Doksologia cui honor et gloria saecula saeculorum ${ }^{174}$ wieńczy myśl św. Antoniego.

\section{Modlitwa z Kazania na Oczyszczenie NMP (In Purificatione BMV)}

Ten najkrótszy tekst w zbiorze sześciu modlitw maryjnych zamyka trzecią część Kazania na Oczyszczenie NMP. Znana z poprzednich

${ }^{170}$ Tamże (II,126,16-18): „Hanc nigredinem et adustionem beata Maria, suae sanctitais medicinali candore, aufert, et in se sperantibus omnimodam confert sanitatem". Tłumaczenie za: SAP, s. 340.

171 In Ann 11 (II,120,18).

172 Por. A w: In Ann 16 (II,126,27-18).

${ }_{173} \mathrm{~B}_{1} \mathrm{w}$ : tamze (II,126,28-29).

${ }^{174} \mathrm{~B}_{2} \mathrm{w}$ : tamize (II,126,30). 
oracji partykuła „zatem” (ergo) ${ }^{175}$ poprzedza wezwanie Matki, której Kaznodzieja nadaje tytuł „Pani nasza”, „wybrana Matka Boga” (Domina nostra, Dei mater electa).$^{176}$ Imię to wskazuje na dar wybrania $^{177}$ i koresponduje z czterema innymi miejscami w pismach św. Antoniego. W samych modlitwach maryjnych odnajdujemy dwa pozostałe wezwania: „Matka Boża Karmicielka” (Dei mater alma) ${ }^{178}$ oraz „sławna Matka Boża” (Dei mater inclita). ${ }^{179}$ Dwa inne miejsca charakteryzują się brakiem formy przyzywającej: „,...przeznaczona jest Matka Boża” (praedestinata est Mater Dei) ${ }^{180}$ oraz: „,błogosławiona Maryja, Matka Syna Bożego" (Beata Maria, Mater Filii Dei). ${ }^{181}$

Antoni zanosi do „wybranej Matki” trzy prośby. W pierwszej z nich wyznaje: „Abyś nas z krwi grzechów oczyścił” (ut a sanguine peccatorum nos purifices). ${ }^{182}$ Samo pragnienie oczyszczenia, wyrażone słowem purifices, koresponduje $\mathrm{z}$ tematem całego kazania i treścią święta Oczyszczenia Maryi (Purificatio Mariae). ${ }^{183}$ Oczyszczająca rola Maryi stanowi ważny element nauczania św. Antoniego: Dziewica wypełnia „prawo twardego serca podczas swoich zaślubin, podczas obrzezania

175 Por. A w: In Pur 9 (II,140,22).

176 Por. $\mathrm{A}_{2}$ w: tamże.

177 Por. J. S c h neide r, dz. cyt., s. 53: „Zwei wesentliche Aussagen, mater und electa, werden beide auf Dei bezogen, unabhängig wie man übersetzt: Gottes erwählte Mutter, die als Mutter Gottes Erwählte, die von Got als Mutter erwählte”.

${ }_{178}$ Por. $A_{2}$ w: In Ann 16 (II,126,23).

179 Por. $\mathrm{A}_{2}$ w: tamże, 5 (II,150,15).

${ }^{180}$ Por. In Ass 2 (II,142,16-18): „Dicamus ergo: «Solium gloriae altitudinis a principio», id est a mundi constitutione, praedestinata est Mater Dei in virtute, secundum spiritum sanctificationis".

${ }^{181}$ Por. In Festo S. Joannis Evangelistae, 7, III,37,21-25: „Beata Maria, Mater Filii Dei, exeniis virtutum, privilegiis gratiarum honorificata, obviavit beato Ioanni ad pedem crucis: ipsa a dextris et ille a sinistris stabant; et ibi, quasi mulier a virginitate sua, suscepit illum, virgo virginem".

${ }_{182} \mathrm{~A}_{3}$ w: In Pur 9 (II,140,22-23).

183 Por. II,127,2 oraz przypisy, wskazujące na możliwe tytuły kazania w manuskryptach: Rubrica: Sermo in Purificatione beatae Mariae Virginis; Titulus: Sermo in Purificatione sanctae Mariae. 
Syna i podczas legalnego oczyszczenia". 184 Zgodnie z podziałem, zawartym w Prologu do Czterech Kazań Maryjnych, temat oczyszczenia został utożsamiony w Sermones z trzema symbolami zaczerpniętymi z Mądrości Syracha (Syr 50,9): kadzidło pachnące we dni letnie, ogień błyskający się i kadzidło gorejące w ogniu. ${ }^{185}$ Pełen alegorii język Antoniego upatruje w podwójnym zbiorze kadzidła podwójne ofiarowanie Chrystusa: „Po raz pierwszy ofiarowała Go Matka w świątyni zgodnie z prawem Mojżeszowym. Po raz drugi sam siebie złożył w ofierze Bogu Ojcu w celu pojednania z nim rodzaju ludzkiego". ${ }^{186}$ Kaznodzieja łączy tu sens słowa „kadzidło” (thus) z greckim słowem „Bóg” (theòs) oraz łacińskim „strzyżenie” (tondendo), ukazując przez to podwójne ofiarowanie Chrystusa w momencie przedstawienia Bogu Ojcu w świątyni i późniejszego „ostrzyżenia” za ludzkie grzechy. ${ }^{187}$ Symbolika podwójnego ofiarowania (duplex Christi oblatio) przeplata się w kazaniu z tematem oczyszczenia, wyrażonego słowami purificare ${ }^{188}$ lub

184 Por. In Ann 2 (II110,24-26): „Morem enim gessit duri corde in sua desponsatione, in Filii circumcisione, in legali purificatione”.Tłumaczenie za: SAP, s. 328. W samym Kazaniu na Oczyszczenie NMP Antoni powraca do wątku wypełnienia Prawa przez Maryję, powołując się przy tym na komentarz glosy (Glo. ord. Lev. 12,8; Lc 2,24): „Ubi et subditur: Quod si non invenerit manus eius, nec poterit offerre agnum, offeret duas turtures, vel duos pullos columbarum (cf. Lev 12,6.8). Haec oblatio pauperum erat, qui offerre agnum non poterat, ut per omnia humilitas et paupertas Domini pateat"; In Pur 7, (II,137,3-9).

${ }_{185}$ Por. Prol II,104,20-22: „In Purificatione: Quasi thus redolens in diebus aestatis; quasi ignis refulgens, et thus ardens in igne“".

${ }^{186}$ In Pur 2 (II,129,3-6): „In duplici collectione thuris duplex Christi oblatio designatur. Primo obtulit eum Mater, «secundum legem Moysi» (Lc 2,22), in templo; secundo obtulit seipsum in sacrificium Deo Patri, in reconciliatione humani generis“.Tłumaczenie za: SAP, s. 342.

${ }^{187}$ Por. In Pur 2 (II,129,6-8): „In prima oblatione fuit «thus», a «theòs» dictum, Deo oblatus; in secunda fuit «thus», a «tondendo» dictum, quia pro peccatis nostris tonsus; et tunc fuit «thus redolens in diebus aestatis », id est fervore iudaicae persecutionis“.

${ }^{188}$ Por. In Pur 7 (II,137,3-5): „Ubi et subditur: Cum expleti fuerint dies, scilicet quadraginta, p u r if i c a t i o $\mathrm{n}$ is eius, offeret agnum ad ostium tabernaculi”, In Pur 9 (II,140,15-17): „Bene ergo dicitur: Quasi ignis effulgens et quasi thus ardens in igne. Iesus Christus in sua Nativitate pastoribus, in sua Apparitione tribus Magis, 
emundare. ${ }^{189}$ Reminiscencja tego zestawienia powraca w pierwszej prośbie analizowanej modlitwy: Maryja, która przyniosła Syna do świątyni, może wyprosić u Boga oczyszczenie z krwi grzechów. Zdolność ta, przypisywana w analizowanej modlitwie Matce, przysługuje w kazaniu de facto samemu Synowi, bowiem to „najwyższy kapłan Jezus Chrystus oczyści z wszelkiego upływu krwi, czyli z nieczystości grzechu" ${ }^{190}$ On też, przyrównany za Eklezjastykiem do rzeki Dorix, przez swoją mękę i krew, leczy ludzkie rany. ${ }^{191}$

Bezpośrednio po pierwszej prośbie następuje kolejne wezwanie do „wybranej Matki”: „[abyś] pomogła nam nieść w wosku spowiedzi i knocie zadośćuczynienia pochodnię skruchy" (ignem effulgentem contritionis, in cera confessionis et stuppa satisfactionis, deferre nos facias). ${ }^{192}$ Słowa te nawiązują w swej treści do obrazów z 9 paragrafu Kazania na Oczyszczenie NMP. Błyskający ogień (ignis effulgens) należy, obok kadzidła (thus), do symboli z Mądrości Syracha przyporządkowanych do kazania. ${ }^{193}$ Ogień i kadzidło to także, według alegorycznego myślenia Kaznodziei z Padwy, symbole samego Chrystusa. Pan zabłysnął potrójnie jak ogień: podczas swego narodzenia, podczas objawienia i podczas oczyszczenia swojej Matki. ${ }^{194} \mathrm{~W}$ czasie swojej męki Chrystus gorzał jak kadzidło w ogniu, a jego zapach napełnił niebiosa, ziemię i otchłań. ${ }^{195}$ Ostatni paragraf kazania, do

in suae Matris Purificatione Simeoni et Annae prophetantibus quasi ignis effulsit" (podkreślenia N. S.).

${ }^{189}$ Por. In Pur 8 (139,17-19): ,Quicumque istiusmodi turtures et columbas obtulerit, ipsum summus sacerdos, Iesus Christus, ab omni profluvio sanguinis, id est immunditia peccati, e m u n d a b i t" (podkreślenie N. S.).

190 Tamże, tłumaczenie za: SAP, s. 350.

${ }^{191}$ Por. In Pur 1 (II,127,21-22): ,[Iesus Christus] factus est nobis (...) Dorix quoad Passionem, in qua sanguinem effudit, quo vulnera nostra sanavit”.

192 Por. $\mathrm{A}_{3}$ w: In Pur 9 (II,140,23-25).

193 Por. Prol, II,104,20-22.

${ }^{194}$ Por. In Pur 9 (II,140,15-17): „Iesus Christus in sua Nativitate pastoribus, in sua Apparitione tribus Magis, in suae Matris Purificatione Simeoni et Annae prophetantibus quasi ignis effulsit".

${ }^{195}$ Por. tamże (II, 17-19): „In sua vera Passione, quasi thus in igne arsit, ex cuius odore, caeli, terra, infernus sunt repleti”. 
którego należy również analizowana modlitwa maryjna, przynosi dokładne wyjaśnienie alegorii ognia. Punktem wyjścia jest tu tradycja przynoszenia do świątyni świecy w Święto Oczyszczenia. Wierni Kościoła „noszą ogień błyskający się na gromnicy, która składa się z knota i wosku. Ogień oznacza Bóstwo, wosk człowieczeństwo, knot szorstkość Męki Pańskiej”. ${ }^{196}$ Obraz gromnicy stanowi dla Antoniego punkt wyjścia do odpowiedniej nauki moralnej. Wszystkie trzy elementy oznaczają dla niego rzeczywistą pokutę: ogień to żar skruchy, wosk to spowiedź z grzechów, a knot to szorstkość zadośćuczynienia. ${ }^{197}$ Druga prośba modlitwy maryjnej zawiera zatem następujące paralele z treścią kazania:

1. wierni przynoszą i ofiarują dzisiaj ogień w świecy ( fideles hodie deferunt et offerunt ignem in candela ${ }^{198}$ ) - ogień oznacza Bóstwo (in igne divinitas $\left.{ }^{199}\right)$ - Błogosławiona Dziewica przyniosła i ofiarowała dzisiaj Syna Bożego w świątyni (Beata Virgo hodie detulit et obtulit Dei et suum Filium in templo ${ }^{200}$ ) - ogień jest symbolem żalu skruchy (in igne ardor contritionis ${ }^{201}$ ) - Maryja ma pomagać nieść ogień błyskający (ignem effulgentem deferre nos facias ${ }^{202}$ ),

2. świeca składa się z wosku i knota (candela constat ex stupa et cera ${ }^{203}$ ) - wosk oznacza człowieczeństwo, a knot szorstkość męki

${ }^{196}$ Tamże (II,139,23-26): „Nota quod hodie Ecclesiae fideles portant ignem effulgentem in candela, quae constat ex stupa et cera. In igne divinitas, in cera humanitas, in stupa dominicae Passionis asperitas designatur”.Tłumaczenie za: SAP, s. 350 .

197 Por. In Pur 9(II139,28-33): „In quibus tribus vera designatur poenitentia. In i g n e, ardor contritionis, omnia eradicans genimina vitiorum. In c e r a , confessio criminis. Sicut enim fluit cera a facie ignis, sic ab ardore contritionis fluit confessio ab ore confitentis, defluentibus lacrimis. In st u pa, asperitas satisfactionis" (podkreślenia N. S.).

198 II,139,27-28.

199 II,139,24-25.

${ }^{200}$ II,139,26-27.

${ }^{201}$ II,139,29-30.

${ }^{202}$ II,140,23-24.

${ }^{203}$ II,139, 24. 
Pańskiej (in cera humilitas, in stupa dominicae Passionis asperitas $^{204}$ ) - wosk jest symbolem spowiedzi (in cera, confessio criminis ${ }^{205}$ )

- knot jest symbolem szorstkości zadośćuczynienia (in stupa, aperitas satisfactionis ${ }^{206}$ )

- Maryja ma pomagać nieść ogień w wosku spowiedzi i knocie zadośćuczynienia (in cera confessionis et stuppa satisfactionis ${ }^{207}$ ).

W trzeciej prośbie Antoni wyraża tęsknotę ludu: „... abyśmy zasłużyli na dojście do światła i chwały niebieskiego Jeruzalem" (quatenus ad lumen et gloriam caelestis Ierusalem pervenire meramur). ${ }^{208}$ Zestawienie słów lumen et gloriam występuje trzy razy w Sermones i jest spotykane wyłącznie w obydwu kazaniach na Oczyszczenie $N M P{ }^{209}$ Jest to fragment Kantyku Symeona: Nunc dimittis. Wyrażenie Ierusalem caelestis pojawia się, oprócz wspomnianej modlitwy, jeszcze dwa razy w pismach maryjnych Padewczyka. Za każdym razem zostaje ono utożsamione $\mathrm{z}$ osobą Matki Pana, kaznodzieja odnosi je, za Izajaszem i glosą, do Córy Syjonu i Kościoła ${ }^{210}$ bądź wprost do Maryi ${ }^{211}$.

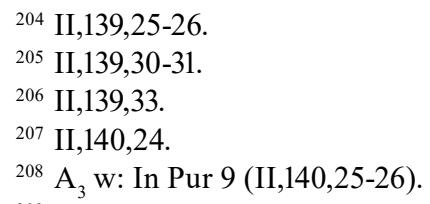

${ }^{209}$ Por. tamże (II,139,33-140,2): „In his tribus est Iesus, idest hominis salus, quae qui Deo obtulerit poterit dicere cum iusto Simeone: «Nunc dimittis servum tuum, Domine, secundum verbum tuum in pace; quia viderunt oculi mei salutare tuum, quod parasti ante faciem omnium populorum: lumen ad reveationem gentium et gloriam plebis tuae Israel» (Lc 2,29-32)“, F Pur 8 (III,108,22-24): „Iste, qui est lumen in praesenti, erit et ad gloriam in futuro «plebis suae Israel»(Lc 2,32), id est videntium Deum". Trzecim miejscem jest analizowana modlitwa maryjna - II,140,25.

${ }^{210}$ Por. In Ann (8,22-26): „Solitudo est beata Virgo, de qua dicit Isaias: «Emitte agnum, Domine», non leonem, «dominatorem terrae», non vastatorem, «de petra deserti», id est beata Virgine, «ad montem filiae Sion» (Is 16,1), id est Ecclesiae, quae est filia Sion, id est caelestis Ierusalem". Antoni powołuje się tu na Iz 16,1 oraz glosę (Glo.ord. Is 16,1) - por. II,115, przypisy 39,40.

${ }^{211}$ Por. F Ann 3 (III,152,19-21): „Pulchra humilitate, amica caritate, suavis contemplatione, decora virginitate, sicut Ierusalem caelestis, in qua habitat Deus, et virgo habitatio ipsius". 
W drugiej części modlitwy Antoni zwraca się do Maryi, nawiązując, po raz kolejny, do tajemnicy dnia: „Za sprawą tego, którego dzisiaj ofiarowałaś w świątyni" (Ipso praestante, quem hodie in templo obtulisti). ${ }^{212}$ Charakterystyczne jest tu użycie słowa „dzisiaj” (hodie), które w znany z poprzednich modlitw sposób, łączy orację $\mathrm{z}$ celebrowanym w święcie wydarzeniem zbawczym. Doksologia: cui est honor et gloria in saecula saeculorum ${ }^{213}$ wieńczy myśl św. Antoniego. Jest ona identyczna z zakończeniem dwóch pozostałych modlitw maryjnych. ${ }^{214}$

\section{Modlitwa z Kazania na Wniebowzięcie NMP (In Assumptione BMV)}

Ostatnia modlitwa typu Rogamus ergo, Domina nostra jest najdłuższą w zbiorze modlitw maryjnych św. Antoniego. Zamyka ona część drugą: O świętości i chwale błogosławionej Maryi Dziewicy (De sanctitate et gloria beatae Mariae Virginis), ${ }^{215}$ a jednocześnie całe kazanie In Assumptione Beatae Mariae Virginis. Zgodnie z tytułem całego fragmentu, modlitwa nawiązuje do świętości i cnót Wniebowziętej Maryi, o czym świadczy zawarte w niej słownictwo jak: „wywyższenie” (exaltatio), ,potęga” (potentia), ,ukoronowanie” (coronatio).

Maryja zostaje wezwana imieniem „sławna Matko Boga” (mater Dei inclita). ${ }^{216}$ Przypomina ono inwokację z dwóch analizowanych wyżej modlitw. ${ }^{217} \mathrm{~W}$ ostatniej modlitwie kaznodzieja rozwija wezwanie następującym opisem: „wywyższona ponad chóry aniołów” (super choros angelorum exaltata). ${ }^{218}$ Zgodnie z konwencją kazania na Uroczystość Wniebowzięcia Maryi, pojawia się tu temat chwały Matki

\footnotetext{
${ }^{212}$ Por. B w: In Pur 9 (II,140,26-27).

${ }^{213} \mathrm{~B}_{2} \mathrm{w}$ : tamże (II,140,27-28).

${ }_{214}$ Por. B ${ }_{2}$ w: In Nat 4 (II,108,13-14); B w: In Ann 16 (II,126,30).

${ }^{215}$ II,144,10-150,27.

216 Por. A w: In Ass 5 (II,150,16).

217 Por. $A_{2}$ w: In Ann 16 (II,126,23); A, w: In Pur 9 (II,140,22).

${ }^{218}$ Por. $\mathrm{A}_{2}$ w: In Ass 5 (II,150,17); J. S c h n e i d e r, Mariologische Gedanken,
} s. $129-130$. 
Bożej wśród chórów anielskich. Analizowana modlitwa nie jest jednak odosobnionym miejscem, w którym Antoni rozważa relację Niewiasty i duchów czystych. Już we wcześniejszych kazaniach pojawia się wiele myśli o charakterze angelologicznym - wyjątkowość narodzenia Maryi na tle narodzin innych świętych ${ }^{219}$ i służba duchów wobec Dziewicy, którą mieli strzec i ochraniać, ${ }^{220}$ pełnia życia anielskiego w Maryi, ${ }^{221}$ wreszcie Jej twarz, pełna wszystkich łask, wdzięczna dla oczu aniołów, którzy pragną na nią patrzeć222. Wyższość Maryi nad aniołami ${ }^{223}$ należy również do często podejmowanych tematów w antoniańskim kaznodziejstwie. I tak Dziewica ma nagrody wszystkich Świętych, ${ }^{224}$ jest Matką umocnienia anielskiego ${ }^{225} \mathrm{i}$ tronem Chrystusa, ${ }^{226} \mathrm{~W}$ chwale niebieskiej, ponad świętymi i aniołami. ${ }^{227}$

219 Por. In Nat 1 (II,105,18-19): ,Sicut stella a stella differt in claritate, sic beatae Virginis Nativitas ab omnium sanctorum differt nativitate".

${ }^{220}$ Por. In Nat 4 (II,108,3-4): ,Sed gloriosa Virgo nec in sua Nativitate habuit maculam, quia in utero matris fuit sanctificata, «ab angelis custodita»..." Antoni powołuje się tu na myśl św. Bernarda; por. B e r n a r d, In Assumptione B.V.M., sermo 2,8, PL 183,420; Epistola 174 (ad Canonicos lugdunenses), 3-5, PL 182,333-334; t e n ż e, Tractatus de Baptismo ad Hugonem, 5,21, PL 132,1044 (II,108 przyp. $22,23)$

${ }^{221}$ Por. In Ann 1 (II,110,2-3): „Porta coeli, ianua paradisi, est beata Maria, in qua verus Salomon sculpsit cherubim, in quibus vita angelica et plenitudo caritatis".

${ }^{222}$ Por. In Ass 3 (II, 147,22-25): „Haec facies etst plena gratiarum omnium, angelorum oculis gratiosa, in quam desiderant prospicere, quae lucet sicut sol in virtute sua".

${ }^{223}$ Por. tamże (II,147,4-7): „Nec enim se vel alium habere voluit ornatorem, sed totam se commisit custodis arbitrio, a quo tam decenter est ornata, ut hodierna die super angelos sit exaltata".

${ }^{224}$ Por. In Pur 6 (II,135,16-18): „Modo vero regnat in gloria, in qua omnium sanctorum habet praemia, quia super choros angelorum exaltata”.

${ }^{225}$ Por. In Ass 1 (II,142,13-15): „Ecce quanta dignitas gloriosae Virginis, quae meruit esse Mater illius, qui est firmamentum et pulchritudo angelorum, et species omnium sanctorum".

${ }^{226}$ Por. J. Schneider, Mariologische Gedanken, s. 127: „Ganz deutlich kommt hier zum Ausdruck, dass ihr Leib Tempel Gottes ist und deshalb verehrt wird. Gerade in ihrer Leiblichkeit ist Maria Ort der Herrlichkeit Gottes und Seiner Engel”.

${ }^{227}$ Por. In Ass 5 (II,150,9-13). 
W ostatniej modlitwie maryjnej znajduje się aż 7 próśb, które Antoni wypowiada w imieniu słuchaczy swojego kazania. Sześć pierwszych próśb skierowanych jest bezpośrednio do „sławnej Matki Boga", przy czym kaznodzieja używa tradycyjnych już form koniunktywnych w 2 . osobie liczby pojedynczej, wskazując przez to na osobę Maryi.

Litanię próśb rozpoczyna wezwanie: „Abyś naczynie serca naszego napełniła niebieską łaską" (ut cordis nostri vas caelestis gratiae impleas). ${ }^{228}$ Jest to jedyne miejsce, w którym Antoni używa poetyckiego obrazu ,naczynie serca” (vas cordis). Samo słowo: vas pojawia się 58 razy w Sermones, 19 razy zaś w Sermones mariani, również w odniesieniu do osoby Dziewicy Matki. ${ }^{229}$ Słowo vas można spotkać wreszcie w Prologu do Quattuor Sermones, gdzie zostało przydzielone do tematu Kazania na Wniebowzięcie NMP: ${ }^{230}$ „...jak naczynie ze złota mocne a całe, wszelkim drogim kamieniem ozdobione" (quasi vas aurum solidum ornatum omni lapide pretioso). ${ }^{231} \mathrm{Nie}$ dziwi więc fakt wielokrotnego użycia obrazu naczynia w tekście samego kazania, wreszcie w kończącej go modlitwie. ${ }^{232}$ Zgodnie z wcześniejszą zapowiedzią, ${ }^{233} \mathrm{w}$ końcowej części kazania następuje rozbudowany wykład kaznodziei na temat wywyższenia Dziewicy. Antoni, przywołując wielokrotnie metaforę ,naczynia ze złota i szlachetnych kamieni” opisuje w nim chwałę i świętość Maryi. Nie dziwi zatem fakt, że użyty przez niego symbol złota (aurum) powraca w drugim

${ }^{228} \mathrm{~A}_{3} \mathrm{w}:$ tamże (II,150,17-18).

${ }^{229}$ Por. In Ann 1 (II,109,18-19): „Beata Maria dicitur v a s , quia thalamus Filii Dei, speciale hospitium Spiritus Sancti, triclinium Sanctae Trinitatis"; tamze (II,109, 22-24): „Hoc v a s fuit «admirabile opus Excelsi», Filii Dei, qui eam prae cunctis mortalibus pulchriorem, prae cunctis sanctis sanctiorem fecit, in qua ipse factus est" (podkreślenia N. S.).

${ }^{230}$ Por. Prol, II,104,22-23: „In Assumptione: Quasi vas auri solidum etc.”.

${ }^{231}$ Cytat z Syr 50,10, w: Prol, II,104,6-7.

232 Por. In Ass 1 (II,141,7-8); In Ass 2 (II,144,8-9); In Ass 3 (II,144,11.12.14.15.29); tamie (II,148,21).

${ }^{233}$ Por. In Ass 2 (II,144,6-9): „Ad laudem ergo ipsius Virginis, quae est expectatio Israel, idest populi christiani, et tantae festivitatis decorem, exponamus praedictam auctoritatem: «Quasi vas auri solidum» (Eccli 50,10-11) etc.”. 
wezwaniu analizowanej modlitwy: „Abyś uczyniła nas jaśniejącymi złotem mądrości" (auro sapientiae effulgere facias). ${ }^{234}$ Wyrażenie „złoto mądrości” (aurum sapientiae) jest dosyć popularne na kartach Sermones. W kalejdoskopie antoniańskich obrazów stanowi ono część poczwórnego zestawienia materiałów: ,złoto mądrości, srebro elokwencji, brąz bogactwa i żelazo mocy" (aurum sapientiae, argentum eloquentiae, aes divitiarum, ferrum potentiae). ${ }^{235} \mathrm{~W}$ swoim rozumieniu ,złota mądrości” Antoni nawiązuje do tradycji patrystycznej, ${ }^{236}$ która widziała w nim symbol odwiecznej mądrości Boga ${ }^{237}$ Doktor Ewangeliczny upatruje w nim również znaczenie świętego i mądrego kaznodziei. ${ }^{238}$ Obok naczynia ze złota pojawia się kolejny symbol: „szlachetne kamienie” (lapides pretiosi). Bogactwo symboliki w pismach Antoniego pozwala na wyodrębnienie wielu znaczeń i treści, jakie kaznodzieja łączy z kamieniem (lapis). ${ }^{239} \mathrm{~W}$ sposób szczególny rzuca się w oczy utożsamienie kamieni szlachetnych z symbolem

${ }^{234} \mathrm{~A}_{3} \mathrm{w}$ : Ass 5 (II,150,18).

${ }^{235}$ Por. Dominica XXII post Pentecosten, 7, II,383,23-27: „Et tunc aurum sapientiae, argentum eloquentiae, aes divitiarum, ferrum potentiae, comminuentur et in nihilum redigentur et a vento dispergentur, quia caro vermibus, divitiae parentibus, anima tradetur daemonibus, et sic nullus inventus erit in eis locus".

${ }^{236}$ Por. M. W a g n e r, Da berühren sich Himmel und Erde. s. 242, przyp. 123, $\mathrm{z}$ dokładnym uwzględnieniem miejsc z Sermones, w których Antoni utożsamia złoto (aurum) z mądrością (sapientia).

${ }^{237}$ Por. tamże, s. 242: „An zahlreichen Stellen der Hl. Schrift ist das Gold - wie Gregor der Große bereits betont - Inbegriff der göttlichen Weisheit, der nichts auf Erden gleichkommt. In dieser Verwendung finden wir das Edelmetall öfter auch bei Antonius“.

${ }^{238}$ W sposób szczególny uwidacznia się to w wykładzie Antoniego o przymiotach kaznodziei: De praedicatoris gratia spirituali et de eiusdem sancta conversatione; por. Dominica XIX post Pentecosten, 1, II,310,30-32: „In auro claritas sapientiae, in purpura sanguis Passionis dominicae, in fibula aurea refrenatio propriae voluntatis designatur”; II,311,30,3-4: „Ille in auro bibit, qui ex claritate sapientiae, quam accepit, prius ipse haurit et postea aliis tribuit“; II,312,10-15: „Si ergo praelatus vel praedicator Ecclesiae in auro sapientiae biberit et in purpura Passionis dominicae fuerit et fibula aurea voluntatem propriam ligaverit, vere cum Iesu in naviculam poterit ascendere, transfretare et in civitatem suam pervenire“.

${ }^{239}$ Por. M. W a g n e r, Da berühren sich Himmel und Erde, s. 225-238. 
cnót: miłosierdziem, posłuszeństwem, cierpliwością i opanowaniem. ${ }^{240}$ Dwanaście szlachetnych kamieni zdobi diadem na głowie Aarona, ${ }^{241}$ stanowiąc - obok dwunastu gwiazd w koronie chwalebnej Dziewicy $^{242}$ - punkt wyjściowy do rozważań w całym zbiorze kazań maryjnych Antoniego.

W takim kontekście zrozumiałym staje się zestawienie obrazu „złotego naczynia, ozdobionego szlachetnymi kamieniami”, do świętości i cnót Matki Bożej. Wykład Antoniego jest tu konsekwentny. Maryja była „naczyniem przez pokorę, złotym przez ubóstwo, mocnym a całym przez dziewictwo, ozdobnym wszelkim drogim kamieniem nagrody, ${ }^{243}$ a ponieważ pokora utrzymuje się przy pomocy ubóstwa, dlatego zwie się naczyniem ze złota, ${ }^{244}$ a ponieważ pokora i ubóstwo Najświętszej Maryi były wyróżnione przez dziewictwo i nienaruszalność, dlatego dodano: Naczynie ze złota mocne a całe. Najświętsza Panienka była mocna i cała przez dziewictwo, i dlatego mogła posiadać w sobie mądrość. ${ }^{245}$ Tamto naczynie było ozdobione w dniu dzisiejszym wszelkim drogim kamieniem, to znaczy pierwszeństwem do nagród niebieskich". 246

${ }^{240}$ Por. Dominica in ramis palmarum, 12, I, 203,15-17: „In his quattuor cornibus fuerunt quattuor lapides pretiosi, qui sunt misericordia, obedientia, patientia et perseverantia“".

${ }^{241}$ Por. Prol, II,104,8-9: „Ecce duodecim lapides pretiosi in diademate capitis Aaron".

${ }^{242}$ Por. Prol, II,104,9-10: „Ecce duodecim stellae in corona gloriosae Virginis”.

${ }^{243}$ In Ass 3 (II,144,11-13): „Beata Maria fuit vas humilitate, auri paupertate, solidum virginitate, omni lapide pretioso praemiorum ornatum“. Tłumaczenie za: SAP, s. 354.

${ }^{244}$ Tamże (II,144,29-30):,Et quia humilitas paupertate conservatur, ideo vas auri dicitur“. Tłumaczenie za: SAP, s. 355.

${ }^{245}$ Tamże (II,145,27-28): „Et quia humilitas et paupertas beatae Mariae virginitatis integritate «fuit» insignita, ideo additur: «Vas auri solidum». Beata Virgo fuit solida virginitate, et ideo sapientiam potuit continere (cf. Eccli 21,17)”. Tłumaczenie za: SAP, s. 355.

${ }^{246}$ Tamże (II,146,2-3): „Istud vas fuit hodierna die omni lapide pretioso, id est omnium praerogativa caelestium praemiorum ornatum". Tłumaczenie za: SAP, s. 355 . 
W trzech wezwaniach z ostatniej modlitwy maryjnej występują wszystkie użyte wcześniej figury retoryczne. W pierwszej prośbie Antoni zestawia symbol „naczynia” (vas) z „sercem” (cor), które ma zostać napełnione „niebieską łaską” (caelestis gratia), ${ }^{247} \mathrm{w}$ drugiej pojawia się „złoto mądrości” (aurum sapientiae), które ma ,jaśnieć” (effulgere) $\mathrm{w}$ słuchaczach kazania, ${ }^{248} \mathrm{w}$ czwartej zaś powraca obraz „drogiego kamienia” (lapis pretiosus), utożsamionego z „,notami” (virtutes), jakimi Maryja ma swoich wiernych „ozdobić" (adornare). ${ }^{249}$ Charakterystycznym jest fakt użycia słowa „kamień” w liczbie pojedynczej (lapis pretiosus), pozostający w konsekwencji do treści kazania $^{250} \mathrm{i}$ cytowanego fragmentu Biblii. ${ }^{251}$ Między tymi prośbami następuje jeszcze trzecie wezwanie: „Abyś umocniła potęgą swej mocy" (tuae virtutis potentia consolides). ${ }^{252}$ Nie zawiera ono żadnego obrazu z Prologu, a jedynie odwołanie do obrazu „umocnienia potęgą". Kaznodzieja przypomina tu własny wykład o umacniającej mocy Chrystusa: „Jezus Chrystus jest utwierdzeniem wysokości, to znaczy anielskiej wyniosłości, którą sam umocnił po upadku buntownika i jego zwolenników (...) Jezus Chrystus, umocnienie anielskiego wyniesienia, jest jego pięknością, tych bowiem, których umacnia mocą swego Bóstwa, tych również nasyca pięknem swego człowieczeństwa". ${ }^{253}$

${ }^{247}$ Por. In Ass 5 (II,150,17-18).

${ }^{248}$ Por. tami̇e (II,150,18).

${ }^{249}$ Por. tamże (II,150,19-20).

${ }^{250}$ Por. In Ass 3 (II,146,2-3): „Istud vas fuit hodierna die omni 1 a p i d e p r e t i o s o, id est omni praerogativa caelestium praemiorum ornatum" (podkreślenie N. S.).

${ }^{251}$ Por. cytat z Syr 50,10-11, w: In Ass 1 (II,141,7-8), lub jego powtórzenie, w: In Ass 3 (II,148,21-22): „Ornatum omni lapide pretioso”.

${ }^{252} \mathrm{~A}_{3} \mathrm{w}$ : In Ass 5 (II,150,18-19).

${ }^{253}$ In Ass 1 (II,141,21-23.142,7-10): „Iesus Christus est firmamentum altitudinis, id est angelicae sublimitatis, quem ipse confirmavit, apostata cum suis sequacibus dilabente (...) Iesus Christus, agelicae sublimitatis firmamentum, ipsius est pulchritudo. Quos enim suae divinitatis potentia consolidat, hos et suae humanitatis pulchritudine satiat".Tłumaczenie za: SAP, s. 352-353. 
Dwie kolejne prośby nawiązują do symbolu oliwy: „Abyś wylała na nas olej miłosierdzia swego, abyś zakryła nim mnogość naszych grzechów" (ut oleum misericordiae tuae, super nos effundas, quo peccatorum nostrorum multitudinem operias). ${ }^{254}$ Do pierwszej z próśb należy dodatkowe wezwanie Maryi imieniem „Ty oliwko błogosławiona" (tu oliva benedicta) ${ }^{255}$ które harmonizuje z zastosowanym przez Antoniego w kazaniu obrazu drzewa oliwnego. Należy on, obok „naczynia ze złota” i „cyprysu”, do trzech symboli, które w Prologu zostały zakwalifikowane do tematu całego Kazania na Wniebowzięcie NMP. ${ }^{256}$ Opierając się na Etymologii św. Izydora, ${ }^{257}$ kaznodzieja z Padwy wyprowadza własną, ${ }^{258}$ daleko idącą alegorię historii zbawienia: „Oliwka jest drzewem, oliwa owocem, a sokiem olej. Drzewo oliwne najpierw wypuszcza pachnący kwiat, z którego powstaje owoc; zrazu jest on zielony, potem czerwony, a później robi się dojrzały. Święta Anna była jakby drzewem oliwnym, z którego wyrósł biały kwiat o nieocenionym zapachu, mianowicie Najświętsza Maryja”. ${ }^{259}$ Ten proces zmiany kolorów i dojrzewania, zaobserwo-

${ }^{254} \mathrm{~A}_{3} \mathrm{w}$ : In Ass 5 (II,150,20-22).

${ }^{255}$ Por. tamże (II,150,20).

${ }^{256}$ Por. Prol, II,104,22-23: „In Assumptione: Quasi vas auri solidum etc.”. Z tego powodu symbole naczynia ze złota, oliwki i wzniosłego cyprysu powracają już w pierwszym zdaniu kazania: „Quasi vas aurum solidum ornatum omni lapide pretioso, quasi oliva pullulans et cypressus in altum se extollens" (II,141,7-8), jak również w późniejszych paragrafach: „Not ista tria: vas, olivam, cypressum” (II,144,11), „Bene ergo dicitur: "Quasi vas auri solidum, ornatum omni lapide pretioso». Sequitur: "Quasi oliva pullulans»" (II,148,21-23).

${ }^{257}$ I s i d o r, Etym. XVII,7,62, PL 82,618, cyt za: II,148, przypis 58.

${ }^{258}$ Por. M. W a g n e r, Da berühren sich Himmel und Erde, s. 187: „Der bildliche Vergleich der Mutter Anna mit dem Olivenbaum, der Gottesmutter Maria mit einer duftenden Blüte und Jesu mit der grünen, roten und reifen Olive ist in dieser Zusammenstellung ein origineller Gedanke des Antonius, der sich so jedenfalls nicht in der Tradition der Patristik wiederfinden lässt“".

${ }^{259}$ In Ass 4 (II,148,23-28): „Olea est arbor; oliva fructus; succus oleum. Olea primo emittit florem odoriferum, ex quo fit oliva, quae est viridis, deinde rubea, deinde efficitur matura. Beata Anna fuit quasi olea, ex qua processit flos candidus, inaestimabilis odoris, scilicet beata Maria..." Tłumaczenie za: SAP, s. 357. 
wany przez Antoniego w świecie natury, zostaje przeniesiony na grunt kaznodziejstwa. W ten sposób Maryja była „zielona” podczas poczęcia i narodzenia Syna Bożego, ${ }^{260}$ zachowując w tych wydarzeniach nienaruszone dziewictwo. ${ }^{261}$ Dziewica była „czerwona” podczas męki Zbawiciela, kiedy miecz boleści przeszył Jej duszę. ${ }^{262}$ Swoją „dojrzałość” osiągnęła zaś podczas wniebowstąpienia, kiedy została wyposażona $w$,,pełnię radości w szczęściu niebieskiej chwały”. ${ }^{263}$

Maryja została zatem utożsamiona $\mathrm{z}$ alegorią dojrzewającego owocu oliwnego (olivae, fructus). W strukturze kazania Antoni pomija jedynie olej (oleum), ostatni symbol w opisywanej triadzie. Słowo to pojawia się dopiero na zakończenie całego tekstu, w modlitwie maryjnej, w której kaznodzieja prosi Matkę Bożą, „oliwkę błogosławioną”, o wylanie na słuchaczy kazania „oleju miłosierdzia" (oleum misericordiae) ${ }^{264}$ Wyrażenie to jest popularne w pismach Doktora z Padwy. U Antoniego sam olej bowiem symbolizuje miłosierdzie. ${ }^{265} \mathrm{~W}$ Sermones pojawia się dodatkowo jeszcze jeden obraz: „oliwa miłosierdzia” (oliva misericordiae). W Kazaniu na Zwiastowanie Doktor Ewangeliczny nazywa tak Maryję. ${ }^{266}$ Znajduje się tam wizja „Błogosławionej Dziewicy, naszej Pośredniczki” (Virgo Maria, mediatrix nostra), ${ }^{267}$ przywracającej pokój między

${ }^{260}$ Por. In Ass 4 (II,148,29-31): „Beata Virgo in Conceptione et Nativitate Salvatoris viridis permansit, vim virginitatis retinuit".

${ }^{261}$ Por. tamże, 4 (II,148,31-149,1): „Virgo ante partum et in partu permansit”.

${ }^{262}$ Por. tamze (II,149,1-2): „Fuit rubea in Filii Passione, quae «ipsius animam pertransivit» (Lc 2,35)".

${ }^{263}$ Por. tamże (II,149,2-4): „Fuit matura in hodierna Assumptione, pullulans, id est pollens cum laetitia, in caelestis gloriae beatitudine".

${ }^{264}$ Por. A 3 : In Ass 5 (II,150,20).

${ }^{265}$ Por. M. W a g n e r, Da berühren sich Himmel und Erde, s. 196: „Am meisten findet sich bei Antonius das Öl als Symbol der Barmherzigkeit, die sich ja bereits in seinem aus dem Griechischen abgeleiteten Namen zeigt“". Ojciec Wagner cytuje wiele miejsc z pism Antoniego, w których autor utożsamia olej z miłosierdziem.

${ }^{266}$ Por. In Ann 11 (II,120,18): „Est enim oliva misericordiae”.

${ }^{267}$ Por. tamże (II,120,11-12). 
Bogiem a grzesznikiem. ${ }^{268}$ To jedyne miejsce w zbiorze Sermones, w którym Antoni używa słowa ,pośredniczka” (mediatrix), stanowi jednocześnie dowód na konsekwencję w wyborze i zastosowaniu alegorii: na przestrzeni różnych kazań kaznodzieja opisuje postać Maryi przy użyciu obrazu oliwy. Jej owocem jest zatem „miłosierdzie" (misericordia). Nietrudno zauważyć, że Doktor Ewangeliczny chętnie pisze o miłosierdziu. W samych Sermones mariani słowo misericordia pojawia się wiele razy. W kaznodziejskim języku Padewczyka zilustrowane jest ono za pomocą obrazu gołębicy, ochraniającej młode, ${ }^{269}$ oznacza ono opiekuńczą i wybaczającą miłość Boga, ${ }^{270}$ a także łaskę okazaną Dziewicy. ${ }^{271} \mathrm{~W}$ ten sposób Maryja stała się „miastem ucieczki” (civitas refugii) 272 i „Matką miłosierdzia” (Mater

${ }^{268}$ Por. tamże (II,130,12-13): „,.. inter Deum et peccatorem pacem reformavit”; J. S c h n e i d e r, Mariologische Gedanken, s. 131: „Weil sie der Ort unserer Heiligung ist, deshlab ist się der Ort unserer Hoffnung(...); Hoffnung deshalb, weil się das Zeichen des Bundes und des Friedens zwischen Gott und den Sündern ist. Zu recht wird się deshalb Mittlerin genannt, weil się den Frieden wiederherstellt"; D. S c a r a $\mathrm{m} \mathrm{u}$ z z i, La figura intelettuale di s. Antonio di Padova, Roma 1934, s. 48.

${ }^{269}$ Por. In Pur 8 (II,139,2-3): „Misericordia est quasi femina pullos custodiens, iustitia est quasi masculus”; tamże (II,139,8-14): „Sed, quia discretio est mater omnium virtutum, sine qua non debet offerri sacrificium, ideo si columba, id est misericordia, retardat ad pullos venire, propter sui partus, id est compunctionis et gemitus dolorem, iustitia, quasi masculus, debet ipsam corrigere et quadam vi intus ponere, ut pullos nutriat et nutriendo custodiat".

${ }^{270}$ Por. F Ann 21 (III,167,26-29): ,Non talis in spiritu indignationis, in commotione damnationis, in gehenna ignis, sed in sibilo aurae tenuis, id est misericordiae ineffabilis". Dizionario Antoniano zamieszcza dokładne omówienie znaczenia słowa misericordia w języku św. Antoniego; por. E. C a r o 1 i (red.), Dizionario Antoniano. Dottrina e spiritualità dei Sermoni di Sant'Antonio, Padova 2002, s. 1045.

${ }^{271}$ Por. In Ass 3 (II,147,33-148,7): „O inextimabilis Mariae dignitas! O inenarrabilis gratiae sublimitas! O ininvestigabilis misericordiae profunditas! Quae tanta gratia, quae tanta misericordia angelo vel homini umquam facta fuit vel fieri potuit, quanta beatae Virgini, quam Deus Pater sui proprii Filii, sibi aequalis, ante saecula geniti, Matrem esse voluit? Maxima foret gratia et dignitas, si aliqua paupercula femina cum Imperatore filium haberet".

${ }^{272}$ Por. IIIQuad L 6 (I,161,27-162,4). W tym wielkopostnym kazaniu maryjnym Antoni porównuje typ starotestamentalnego miasta ucieczki do imienia Maryi, ukazując w tym dzieło Bożego miłosierdzia: „Sicut enim quondam Dominus, ut 
misericordiae), ${ }^{273} \mathrm{którą} \mathrm{Antoni} \mathrm{prosi} \mathrm{-} \mathrm{w} \mathrm{imieniu} \mathrm{swoich} \mathrm{słuchaczy} \mathrm{-}$ o wylanie oleju miłosierdzia i zakrycie nim ludzkich grzechów.

W siódmej prośbie występuje ponownie konstrukcja „abyśmy zasłużyli" (ut mereamur). W przypadku analizowanej modlitwy nie łączy się ona jednak z czasownikiem pervenire (jak to było we wszystkich pozostałych oracjach), ale z dwoma innymi słowami. Antoni prosi: „Abyśmy zasłużyli na wyniesienie na wysokość niebieskiej chwały i bycie szczęśliwymi ze świętymi” (qua ad caelestis gloriae altitudinem sublevari et cum beatis beatificari mereamur). ${ }^{274}$ Na uwagę zasługuje tu podwójny cel proszących: „niebieska chwała” (gloria caelestis) oraz „stan szczęścia ze świętymi” (cum beatis beatificari). Obydwa obrazy symbolizują stan zbawienia i wiecznej szczęśliwości. W obrazowym języku Kazań maryjnych „chwała niebieska" to owoc drzewa życia, ${ }^{275}$ symbol wiecznej chwały Wnie-

dicitur in libro Numeri, «separavit civitates refugii, ad quas confugeret qui nolens homicidium perpetraret»; sic nunc misericordia Domini refugium misericordiae nomen Mariae providit etiam voluntariis homicidis". Por. G.C. M o r a l e j o, Santa Maria en los Sermones de S. Antonio de Padua, s. 348: „Y por la unión que garda María la Virgen Madre con su Hijo, Ella es, con toda propriedad, la Madre de misericordia y su testigo excepcional para la humanidad entera. María es como la ciudad de refugio que el Señor ha puesto a nuestro alcance para que la elijamos (Num. 35,11) como asilo de misericordia”.

273 Por. F Pur 9 (III,110,4-6): „Nullum animal, id est peccatorem, fugit, immo omnes ad se confugientes recipit, et ideo vocatur mater misericordiae: misericors miseris, spes desperatis“. Bardzo trafny komentarz do tego miejsca zamieszcza R. L a u r e n t i n, La Vierge Marie chez Saint Antoine de Padoue, s. 495: „Le titre de Mère de miséricorde, qu'on trouve du Xe siècle était largement répandu au temps de saint Antoine. Il y fait écho. Mais en quel sens? Originellement, ce titre signifiait Mère du Christ qui est la Miséricorde en personne. Tel est bien le sens entendu par saint Pierre Damien, mort en 1072 (...) Ici Pierre Damien requiert i'intercession de Marie et réfère aux hommes sa Miséricorde, mais pa sa Maternité. Y a-t-il plus chez Antoine de Padouve? Ce n'est pas évident. Il n'est pas prouvé jusqu'à ce jour qu'il se soit adressé à Marie comme à sa mère".

${ }^{274} \mathrm{~A}_{3}$ w: In Ass 5 (II,150,22-23).

275 Por. F Pur 12 (III,116,34-117,6): „Lignum, poenitens, qui plantatur secus decursus aquarum, id est lacrimarum vel abundantiam gratiarum; cuius radix, humilitas; truncus ex ipsa procedens, obedientia; rami, caritatis opera, ad amicum 
bowziętej, stanowiący jej diadem, ${ }^{276}$ kontemplację ${ }^{277}$ i szczęście. ${ }^{278}$ Wyrażenie „ze świętymi” (cum beatis) występuje w pismach maryjnych tylko jeden raz, w pozostałych zaś pismach pięć razy, łącząc się z określeniami mieszkańców nieba: ,ze świętymi duchami” (cum beatis spiritibus), ${ }^{279}$, ,świętymi aniołami” (cum beatis angelis) ${ }^{280}$, „świętymi Młodziankami” (cum beatis innocentibus). ${ }^{281}$ Ostatnia prośba nabiera więc, w świetle omówionych dwóch konstrukcji: gloria celestis oraz cum beatis charakteru ściśle eschatologicznego i w sposób przemyślany zamyka treść Kazania na Wniebowzięcie NMP.

Druga część oracji nawiązuje również do tajemnicy święta. Służy temu nie tylko występująca we wszystkich antoniańskich modlitwach aktualizacja: „w dniu dzisiejszym” (hodierna die), ale również ponowne przytoczenie obrazów ze sceny wywyższenia Maryi: „Za sprawą Jezusa Chrystusa, Syna Twego, który Cię w dniu dzisiejszym wyniósł ponad chóry aniołów, ukoronował diademem królestwa i umieścił na tronie wiecznego progu" (Praestante Iesu Christo, filio tuo, qui te hodierna die super choros angelorum exaltavit, diademate regni coronavit et in solio aeterni liminis collocavit). ${ }^{282}$ Antoni wykorzystuje w tej części modlitwy następujące obrazy z samego

et inimicum se extendentia; folia, vitae aeternae verba; fructus, caelestis gloria, quae habet initium, medium et finem sine fine“.

${ }^{276}$ Por. In Ass 3 (II148,17-18): ,...ideo idem Filius suam Matrem coronavit hodierna die diademate gloriae caelestis“.

${ }^{277}$ Por. F Pur 9 (III,109,14-15): „Haec bona apis fuit parva humilitate, rotunda contemplatione caelestis gloriae..."

${ }^{278}$ Por. In Ass 4 (II,149,2-4): ,... fuit matura in hodierna Assumptione, pullulans, idest pollens cum laetitia, in caelestis gloriae beatitudine“.

${ }^{279}$ Por. In Ascensione Domini 5, III,241,25-26: „... quanta erit illa gloria cum beatis spiritibus vultui Creatoris assistere..."

${ }^{280}$ Por. Dominica II post Pentecosten 3, I,419,26-27: ,... in cuius gloriae cena cum beatis angelis epulantur“; Dominica VI post Pentecosten 15, I,530,8-9: ,... munera laudis cum beatis angelis tibi Deo valeamus offerre".

${ }^{281}$ Por. In Festo Sanctorum Innocentium 14, III,54,5-7: „Rogemus Dei Filium, ut in hac triplici mensa ita refici, ut in mensa caelesti cum beatis Innocentibus mereamur satiari“".

${ }^{282}$ Por. B 1 w: In Ass 5 (II,150,23-26). 
kazania: wywyższenie ponad aniołów, ${ }^{283}$ ukoronowanie diademem królestwa ${ }^{284}$ i umieszczenie na tronie. ${ }^{285}$ Kaznodziejska dokładność nakazuje zaś Padewczykowi utrzymać w finalnej modlitwie wcześniej w prowadzoną konsekwencję obrazów. $Z$ tego powodu zapowiedź alegorii znajduje się w pierwszym paragrafie kazania, pierwszy obraz pochodzi z drugiego paragrafu kazania, drugi z trzeciego a ostatni z piątego. Całość tekstu modlitwy została zwieńczona rozbudowaną doksologią. W jej skład wchodzi nie tylko tradycyjne zdanie: Cui est honor et gloria per aeterna saecula, ale również druga część, jakby dopowiedzenie: Dicat omnis Eccesia: Amen. Alleluia. ${ }^{286}$ Wezwanie całego Kościoła do potwierdzenia chwały Wniebowziętej Maryi zamyka ostatnią modlitwę maryjną i cały zbiór Czterech Kazań na święta Błogosławionej Dziewicy Maryi.

\section{Elementy mariologii św. Antoniego z Padwy w modlitwach. Próba syntezy}

Modlitwy maryjne są wyrazem nie tylko głębokiej pobożności i zaufania względem Matki Bożej, lecz również przykładem znajomości historii i liturgii Kościoła oraz oryginalności własnej myśli teologicznej. ${ }^{287}$ Święty wyraża w nich osobistą pobożność maryjną, zakorzenioną $\mathrm{w}$ tradycji kościelnej, zawierającą jednak liczne zapożyczenia od św. Bernarda i duchowości franciszkańskiej. ${ }^{288} \mathrm{~W}$ porównananiu

${ }^{283}$ Por. In Ass 2 ( II,143,23-25); tamże (II,144,2-5).

${ }^{284}$ Por. tamize, 3 (II,148,10-22).

${ }^{285}$ Por. tamże, 5(II,150,6-15).

${ }^{286}$ Por. B w: tamże (II,150,26-27).

${ }^{287}$ Por. The Marian devotion of St. Anthony of Padua, Ephemerides Mariologicae 47/1997, s. 285: „His devotion was founded on the solid foundation of Catholic doctrine, as all true devotion is. Consequently he has left the Church with a wealth of mariological insights in his sermons. Reflecting upon the doctrines about our Blessed Lady throught the eyes of St. Anthony one realizes with him that in Her were gathered all the privileges of merits and rewards".

${ }^{288}$ Por. L. P ol o n i a t o, Le preghiere dei Sermones di S. Antonio di Padova, s. 22: „Il santo, nel verbalizzere la sua devozione verso la Madonna si inserisce pienamente sulla scia dell'antichissima devozione mariana ecclesiale, anche se 
$\mathrm{z}$ innymi modlitwami z Sermones ${ }^{289}$ ton wypowiedzi jest tu mniej oficjalny, bardziej osobisty, słodki, ale nie przesłodzony, ${ }^{290}$ zdominowany wołaniem dziecka do swojej niebieskiej matki w ufności, że zanoszone prośby zostaną wysłuchane i spełnione. ${ }^{291}$ Wykreowany przez Antoniego obraz Matki Bożej jest pełen ciepła i bliskości, Maryja to przede wszystkim Oblubienica i Matka, obecna w ziemskim życiu Chrystusa i w duchowym życiu Kościoła. ${ }^{292}$

Oprócz wielości imion nadanych Maryi, które - jak wspomniano nawiązują do treści wybranych kazań modlitwy zawierają konkretną wizję udziału Maryi w Chrystusowym planie zbawienia i życiu Kościoła. ${ }^{293} \mathrm{~W}$ samym katalogu imion maryjnych, ${ }^{294}$ spotykanych częściowo także w analizowanych modlitwach, uwidaczniają się wspomniane wpływy św. Bernarda z Clairvaux. „Są to typowe tytuły bernardyńskie, którymi pozdrawia się Maryję: błogosławiona Matka Boża, imię najsłodsze, imię łagodnej i błogosławionej nadziei, bezpieczny port, księżyc w pełni, pod każdym względem doskonały, tron chwały". ${ }^{295}$ Nie można jednak u Antoniego pominąc szkoły franciszkańskiej. „Echem franciszkańskim odbijają się tytuły: paupercula Femina, Porta coeli, ianua paradisi, Turris fortissimo, Thalamo glo-

certi accenti vanno fatti risalire chiaramente a $\mathrm{s}$. Bernardo e alla spiritualità di s. Francesco“".

${ }^{289}$ Por. Preghiera, orazione, contemplazione, w: E. C a r o 1 i (red.), Dizionario Antoniano, s. 635-647.

${ }^{290}$ Por. L. P o l o n i a t o, Le preghiere dei Sermones di S. Antonio di Padova, s. 21-22: „Il tono colloquiale si fa più dolce, anche se non scade mal nelle sdolcinature: è il figlio che invoca la madre celeste, la Benigna Madre di Dio, sapendo che il cuore di lei è sempre amorevolmente disposto all'aiuto e alla comprensione"; R. L a u r e n i n, La Vierge Marie chez Saint Antoine de Padoue, s. 494-495.

${ }^{291}$ Por. G.M. R o s c h i n i, La mariologia di s. Antonio di Padova, s. 62-66.

${ }^{292}$ Por. D.C. A fo n s o, De Virgo paupercula a Domina potente. Uma Mariologia evocativa em Antonius Patavinus, Roma 2012, s. 7.

${ }^{293}$ Por. L. P o lo n i t o, Le preghiere dei Sermones di S. Antonio di Padova, s. 25: „...le orazioni rivolte alla Beata Vergine Maria non sono mai come a interlocutore divino, ma nella totalità dei casi in relazione al Figlio..."

${ }^{294}$ Por. Maria, w: E. C a r o 1 i (red.), Dizionario Antoniano, s. 449-462.

${ }^{295}$ L. P o 1 o n i a t o, Le preghiere dei Sermones di S. Antonio di Padova, s. 22. 
riae, które mogą zostać zestawione z Pozdrowieniem Błogosławionej Dziewicy Maryi św. Franciszka". 296

Pobożność antoniańska w sposób świadomy kładzie akcent na chrystologię. Jezus stoi w centrum modlitwy kaznodziei z Padwy. Taka postawa może być jednak praktykowana w łączności z chwaleniem, dziękczynieniem i przeżywaniem tajemnic maryjnych, medytacją tych misteriów, wreszcie modlitwą i przyzywaniem Matki Bożej, naśladowaniem Jej cnót i kaznodziejskim głoszeniu Jej chwa$ł y .{ }^{297}$ Wszystkie te elementy dadzą się odkryć i sklasyfikować w maryjnych modlitwach świętego z Padwy.

Następujące zestawienie ${ }^{298}$ ma na celu ukazanie krótkiej syntezy mariologii antoniańskiej.

1. Maryja, nasza nadzieja i gwiazda morza, oświeca ludzką drogę, doprowadza do portu zbawienia i towarzyszy człowiekowi w jego przejściu z niewoli do nieskończonego szczęścia.

2. Maryja, jako gwiazda zaranna, rozpędza mgłę pokus szatańskich, jako księżyc w pełni, wypełnia pustkę ludzkich serc, obmywa i rozjaśnia ciemność dusz, pomagając przez to w dojściu do światła nieskończonej chwały.

3. Maryja, jedyna nadzieja, oświeca dusze, oczyszcza i rozgrzewa je światłem i ciepłem swojej łaski, a przez to doprowadza do pojednania z Jej Synem i dojścia do blasku Jego chwały.

${ }^{296}$ Tamże.

${ }^{297}$ Por. L. di Fo n z o, La mariologia di S. Antonio, s. 165: „Tale devozione dev'essere praticata e manifestata, secondo il Nostro, con la lode, congratulazione e compartecipazione ai Misteri Mariani; con la meditazione di quegli misteri cristologico-mariani; con l'invocazione e la preghiera continua; con l'imitazione delle virtù mariane e amore fattivo; finalmente, con la «predicazione» (quasi apostolato mariano diremmo oggi)“.

Por. B. C o s t a, La mariologia di S. Antonio di Padova, s. 157: „Qui devozione sta per culto, onore. S. Antonio orienta la devozione a Maria verso due punti principali: privilegi e virtù mariane".

${ }^{298}$ Cyfry arabskie odpowiadają kolejnym modlitwom maryjnym. W celu ułatwienia syntezy zrezygnowano z łacińskich odpowiedników. 
4. Maryja, Matka Boża Karmicielka, wyprasza grzesznikom przebaczenie u Jej Syna, leczy dusze miłosierdziem i pomaga w dojściu do radości wiecznego święta.

5. Maryja, wybrana Matka Boża, oczyszcza dusze z krwi grzechów i pomaga w czynieniu pokuty, kierując dusze ku chwale niebieskiego Jeruzalem.

6. Maryja, sławna i ponad aniołów wywyższona Matka Boża, napełnia serca ludzkie niebieską łaską, mądrością i wszelkimi cnotami, namaszcza dusze olejem miłosierdzia i zakrywa grzechy, prowadząc do niebieskiej chwały i szczęścia ze świętymi.

Przytoczona powyżej próba syntezy myśli mariologicznej, zawartej w analizowanych modlitwach, wskazuje wyraźnie na podwójny cel kaznodziejstwa antoniańskiego: ma pokrzepić dusze słuchaczy (consolatio), ukazując wiernym dobroć i bliskość Matki Bożej, jednocześnie ma przygotować innych kaznodziejów (aedificatio), aby owocnie głosili chwałę Chrystusa i Jego Matki. Nad wszystkim zaś góruje antoniański cel moralny, ,aby doprowadzić słuchaczy do pokuty i pomóc im do uświęcenia". ${ }^{299}$ Obrazy, zaczerpnięte z Biblii i Tradycji, ze świata przyrody ożywionej i nieożywionej, pomagają Antoniemu ukazać podstawowe tajemnice i prawdy maryjne. „Święty nie stawia problemów teologicznych, nie udowadnia prawd wiary, czy przykazań moralnych, ale je omawia, objaśnia i stosuje do życia". 300

$$
* * *
$$

„Arcydzieło Boga - Maryja, była przedziwnym dziełem Najwyższego, Jego arcydziełem, ponieważ była najpiękniejszą ze wszystkich śmiertelnych, najświętszą ze wszystkich świętych". ${ }^{301}$ Powyższy cytat z Kazania na Zwiastowanie NMP ukazuje zachwyt św. Antoniego nad postacią Maryi, Dziewicy i Matki, chwalebnej Pani. Szczególna więź, jaka łączyła świętego z Padwy z Matką Pana, nie mogła pozo-

${ }^{299}$ C. N i e z g o d a, Św. Antoni z Padwy. Życie i nauczanie, s. 179.

${ }^{300}$ Tamże.

${ }^{301}$ In Ann 1 (II,109,22-24). Tłumaczenie za: SAP, s. 244. 
stać bez wpływu na jego działalność nauczycielską i kaznodziejską w zakonie franciszkańskim. Mimo że trudno mówić u Antoniego o typowo scholastycznym wykładzie mariologii, znajdujemy w jego pismach wiele dojrzałych i przemyślanych myśli o Maryi.

Sześć wyżej omówionych tekstów maryjnych nie jest kompletnym wykładem duchowości maryjnej św. Antoniego. Analizowane fragmenty nie są bowiem jedynymi modlitwami na kartach Sermones. $\mathrm{Z}$ drugiej strony nie wyczerpują one również zakresu mariologii antoniańskiej, gdyż święty wypowiada się o Matce Bożej w wielu innych miejscach swoich kazań. Mimo tych ograniczeń, modlitwy Rogamus te, Domina nostra, posłużyły za punkt wyjścia do analizy myśli franciszkańskiej XIII w., której znakomitym przedstawicielem jest kaznodzieja z Padwy, pierwszy nauczyciel wśród Braci Mniejszych.

\section{Dodatek \\ Zestawienie 6 modlitw maryjnych św. Antoniego z Padwy Rogamus te, Domina nostra}

A - część I, w której Antoni zwraca się do Maryi

$\mathrm{A}_{1}$ - inwokacja

$\mathrm{A}_{2}$ - wyliczenie imion i tytułów Maryi $\left(\mathrm{A}_{2 \mathrm{~A}}-\right.$ ewentualne rozwinięcie)

$\mathrm{A}_{3}$ - prośba (część koniunktywna), zakończona wezwaniem (mereamur) pervenire

B - część II, w której Antoni zwraca się do Chrystusa

$\mathrm{B}_{1}$ - część chrystologiczna, zmienna w zależności od święta

$\mathrm{B}_{2}-$ doksologia

Słowa w nawiasie kwadratowym pełnią funkcję pomocniczą, w celu lepszego zrozumienia łacińskiego tekstu. 


\begin{tabular}{|c|c|c|}
\hline symbol & tekst laciński & tekst polski \\
\hline & \multicolumn{2}{|c|}{$\begin{array}{c}\text { Dominica III in Quadragesima-intero sermone: } \\
\text { In laudem Beatae Mariae Virginis } \\
\text { III Quad L } 7(\mathrm{I}, 163,3-9)\end{array}$} \\
\hline$A_{1}$ & Rogamus ergo & Prosimy [Cię] zatem \\
\hline $\mathrm{A}_{2}$ & $\begin{array}{l}\text { Domina nostra, } \\
\text { spes nostra }\end{array}$ & $\begin{array}{l}\text { Pani nasza, } \\
\text { nadziejo nasza, }\end{array}$ \\
\hline $\mathrm{A}_{3}$ & $\begin{array}{l}\text { ut nobis huius maris tempe- } \\
\text { state concussis, }\end{array}$ & \multirow{2}{*}{$\begin{array}{l}\text { abyś nas, } \\
\text { Gwiazdo morza, } \\
\text { burzą tego morza } \\
\text { wstrząśniętym, }\end{array}$} \\
\hline $\mathrm{A}_{2}$ & tu, stella maris, & \\
\hline $\mathrm{A}_{3}$ & $\begin{array}{l}\text { irradies, } \\
\text { ad portum dirigas, } \\
\text { exitum nostrum tuae praesen- } \\
\text { tiae tutela munias, } \\
\text { ut a carcere securi exire }\end{array}$ & $\begin{array}{l}\text { oświeciła, } \\
\text { do portu doprowadziła, } \\
\text { nasz koniec obwarowała } \\
\text { opieką Twojej obecności, } \\
\text { abyśmy bezpiecznie wyszli } \\
\text { z niewoli }\end{array}$ \\
\hline & $\begin{array}{l}\text { et ad gaudium infinibile laeti } \\
\text { mereamur pervenire. }\end{array}$ & $\begin{array}{l}\text { i z radością mogli zasłużyć } \\
\text { na dojście do nieskończonego } \\
\text { szczęścia. }\end{array}$ \\
\hline$\overline{\mathrm{B}_{1}}$ & $\begin{array}{l}\text { Ipso praestante, } \\
\text { quem beato ventre portasti, } \\
\text { uberibus sacratissimis } \\
\text { lactasti. }\end{array}$ & $\begin{array}{l}\text { Za sprawą tego, } \\
\text { którego nosiłaś w błogosła- } \\
\text { wionym łonie, } \\
\text { najświętszymi piersiami } \\
\text { karmiłaś. }\end{array}$ \\
\hline $\mathrm{B}_{2}$ & $\begin{array}{l}\text { Cui est honor et gloria per } \\
\text { aeterna saecula. Amen. }\end{array}$ & $\begin{array}{l}\text { Któremu jest cześć i chwała } \\
\text { na wieki wieków. Amen. }\end{array}$ \\
\hline
\end{tabular}

\section{In Nativitate Beatae Mariae Virginis}

De beata Maria Salvatoris nuncia et ex omni parte perfecta

In Nat 4 (II,108,6-14)

\begin{tabular}{lll}
\hline $\mathrm{A}_{1}$ & Rogamus ergo te, & Prosimy zatem Cię, \\
\hline $\mathrm{A}_{2}$ & Domina nostra, & Pani nasza, \\
& ut tu, quae es stella matutina,, & $\begin{array}{l}\text { abyś Ty, która jesteś gwiazdą } \\
\text { zaranną, }\end{array}$ \\
\hline
\end{tabular}




\begin{tabular}{lll}
\hline symbol & \multicolumn{1}{c}{ tekst laciński } & \multicolumn{1}{c}{ tekst polski } \\
\hline $\mathrm{A}_{3}$ & $\begin{array}{l}\text { nebulam daemoniacae sugge- } \\
\text { stionis, mentis nostrae terram } \\
\text { tegentem, } \\
\text { tuo splendore expellas; }\end{array}$ & $\begin{array}{l}\text { mgłę szatańskiego podszeptu, } \\
\text { okrywającą świat naszego } \\
\text { ducha, swym blaskiem } \\
\text { rozpędziła }\end{array}$ \\
\hline $\mathrm{A}_{2}$ & tu, quae es plena luna, & $\begin{array}{l}\text { Ty, która jesteś księżycem } \\
\text { w pełni, }\end{array}$ \\
\hline $\mathrm{A}_{3}$ & vacuitatem nostram & [abyś] pustkę naszą wypeł- \\
& adimpleas, & niła, ciemność grzechów \\
& peccatorum nostrorum tene- & naszych obmyła, \\
& bras diluas, & abyśmy tam zasłużyli na \\
& quatenus ad vitae aeternae & dojście \\
& plenitudinem, & do pełni życia wiecznego, \\
ad gloriae indeficientis lucem & do światła chwały \\
pervenire mereamur. & nieskończonej. \\
& Ipso praestante, & Za sprawą tego, \\
qui in te lucem nostram & który w Tobie stał się naszym \\
produxit; & światłem, \\
$\mathrm{B}_{1}$ & który, aby z Ciebie się naro- \\
& qui ut ex te nasceretur, & dzić, sprawił, że się dzisiaj \\
& ne hodie nasci fecit. & Któremu jest cześć i chwała \\
& Cui est honor et gloria in & na wieki wieków. \\
& saecula saeculorum. & Amen. \\
\hline $\mathrm{B}_{2}$ & Amen. &
\end{tabular}

In Annuntiatione beatae Mariae Virginis

I. De virtutibus et praerogativis beate Mariae Virginis

In Ann 6 (II,114,24-31)

\begin{tabular}{lll}
\hline$A_{1}$ & Eia ergo, & A więc, \\
\hline$A_{2}$ & Domina nostra, spes unica, & Pani nasza, nadziejo jedyna, \\
\hline$A_{1}$ & supplicamus tibi, & prosimy Cię pokornie, \\
\hline
\end{tabular}




\begin{tabular}{lll}
\hline symbol & \multicolumn{1}{c}{ tekst laciński } & \multicolumn{1}{c}{ tekst polski } \\
\hline $\mathrm{A}_{3}$ & ut mentes nostras splendore & abyś nasze dusze światłem \\
& tuae gratiae illumines, & Twojej łaski oświeciła, \\
& candore tuae munditiae & jasnością Twojej czystości \\
& emundes, & oczyściła, \\
& calore tuae visitationes & ciepłem Twojego nawiedzenia \\
& calefacias, & ogrzała, \\
& & z Synem Twoim nas po- \\
& filio tuo nos reconcilies, & jednała, abyśmy zasłużyli \\
& qua ad ipsius gloriae splendo- & na dojście do blasku jego \\
& rem pervenire mereamur. & chwały. \\
\hline $\mathrm{B}_{1}$ & Ipso praestante, & Za sprawą tego, \\
& qui angelo nuntiante, & który przez zwiastowanie \\
& hodierna die, & anielskie, \\
& ex te gloriosam carnem & w dniu dzisiejszym, \\
& assumere & zechciał wziąc z Ciebie chwa- \\
& & lebne ciało \\
& et in tuo thalamo novem men- & i zamieszkać w Twoim łonie \\
& sibus voluit habitare. & przez dziewięć miesięcy. \\
\hline $\mathrm{B}_{2}$ & Cui honor et gloria per & Któremu jest cześć i chwała \\
& aeterna saecula. Amen. & na wieki wieków. Amen. \\
\hline
\end{tabular}

\section{In Annuntiatione Beatae Mariae Virginis}

III. De Nativitate Domini

In Ann 16 (II,126,23-30)

\begin{tabular}{lll}
\hline $\mathrm{A}_{1}$ & Rogamus ergo te, & Prosimy Cie zatem, \\
\hline $\mathrm{A}_{2}$ & Domina nostra, & Pani nasza, \\
& $\begin{array}{l}\text { Dei mater alma, } \\
\text { ut in hac nativitate filii tui, }\end{array}$ & $\begin{array}{l}\text { Boga Matko Karmicielko, } \\
\text { abyś w tym narodzeniu Syna } \\
\end{array}$ \\
& Twojego, \\
& quem virgo peperisti, & którego jako Dziewica poro- \\
pannis involvisti, & dziłaś, owinęłaś w pieluszki, \\
& in praesepio reclinasti, & w żłobie położyłaś, \\
\hline
\end{tabular}




\begin{tabular}{|c|c|c|}
\hline symbol & tekst laciński & tekst polski \\
\hline $\mathrm{A}_{3}$ & $\begin{array}{l}\text { indulgentiam nobis ab ipso } \\
\text { impetres, } \\
\text { adustionem animae nostrae, } \\
\text { quam ex igne peccati } \\
\text { contraximus, } \\
\text { tuae misericordiae emplastro } \\
\text { sanes, } \\
\text { qua ad aeternae festivi- } \\
\text { tatis gaudium pervenire } \\
\text { mereamur. }\end{array}$ & $\begin{array}{l}\text { abyś nam Jego przebaczenie } \\
\text { wyprosiła, } \\
\text { oparzenie naszej duszy, } \\
\text { jakie doznaliśmy od ognia } \\
\text { grzechu, } \\
\text { plastrem miłosierdzia Two- } \\
\text { jego uleczyła, } \\
\text { abyśmy zasłużyli na dojście } \\
\text { do radości wiecznego święta. }\end{array}$ \\
\hline $\mathrm{B}_{1}$ & $\begin{array}{l}\text { Ipso praestante, } \\
\text { qui ex te, gloriosa Virgine, } \\
\text { hodie nasci dignatus est. }\end{array}$ & $\begin{array}{l}\text { Za sprawą tego, } \\
\text { który z Ciebie, chwalebnej } \\
\text { Dziewicy, } \\
\text { raczył się dziś narodzić. }\end{array}$ \\
\hline $\mathrm{B}_{2}$ & $\begin{array}{l}\text { Cui honor et gloria in saecula } \\
\text { saeculorum. } \\
\text { Amen. }\end{array}$ & $\begin{array}{l}\text { Któremu jest cześć i chwała } \\
\text { na wieki wieków. } \\
\text { Amen. }\end{array}$ \\
\hline
\end{tabular}

In Purificatione Beatae Mariae Virginis

III. De multiplici oblatione Virginis

In Pur 9 (II,140,22-28)

\begin{tabular}{lll}
\hline $\mathrm{A}_{1}$ & Rogamus te ergo, & Prosimy Cię zatem, \\
\hline $\mathrm{A}_{2}$ & $\begin{array}{l}\text { Domina nostra, Dei mater } \\
\text { electa, }\end{array}$ & $\begin{array}{l}\text { Pani nasza, Matko Boga } \\
\text { wybrana, }\end{array}$ \\
\hline
\end{tabular}




\begin{tabular}{|c|c|c|}
\hline symbol & tekst laciński & tekst polski \\
\hline $\mathrm{A}_{3}$ & $\begin{array}{l}\text { ut a sanguine peccatorum nos } \\
\text { purifices, } \\
\text { ignem effulgentem } \\
\text { contritionis, } \\
\text { in cera confessionis } \\
\text { et stuppa satisfactionis, } \\
\text { deferre nos facias, } \\
\text { quatenus ad lumen et gloriam } \\
\text { caelestis Ierusalem pervenire } \\
\text { mereamur. }\end{array}$ & $\begin{array}{l}\text { abyś nas z krwi grzechów } \\
\text { oczyściła, } \\
\text { [abyś] pomogła nam } \\
\text { nieść pochodnię skruchy, } \\
\text { uczyniła nas woskiem } \\
\text { w spowiedzi } \\
\text { i knotem zadośćuczynienia, } \\
\text { abyśmy zasłużyli na dojście } \\
\text { do światła i chwały niebie- } \\
\text { skiego Jeruzalem. }\end{array}$ \\
\hline $\mathrm{B}_{1}$ & $\begin{array}{l}\text { Ipso praestante, } \\
\text { quem hodie in templo } \\
\text { obtulisti. }\end{array}$ & $\begin{array}{l}\text { Za sprawą tego, } \\
\text { którego dzisiaj w świątyni } \\
\text { ofiarowałaś. }\end{array}$ \\
\hline $\mathrm{B}_{2}$ & $\begin{array}{l}\text { Cui est honor et gloria in } \\
\text { saecula saeculorum. } \\
\text { Amen. }\end{array}$ & $\begin{array}{l}\text { Któremu jest cześć i chwałą } \\
\text { na wieki wieków. } \\
\text { Amen. }\end{array}$ \\
\hline
\end{tabular}

In Assumptione Beatae Mariae Virginis

De sanctitate et gloria beatae Mariae Virginis

In Ass 5 (II,150,16-27)

\begin{tabular}{lll}
\hline $\mathrm{A}_{1}$ & Rogamus ergo te, & Prosimy Cię zatem, \\
\hline $\mathrm{A}_{2}$ & Domina nostra, mater Dei & Pani nasza, sławna Matko \\
& $\begin{array}{l}\text { inclita, super choros angelo- } \\
\text { rum exaltata, }\end{array}$ & $\begin{array}{l}\text { Boga, ponad chóry aniołów } \\
\text { wywyższona, }\end{array}$ \\
\hline
\end{tabular}




\begin{tabular}{|c|c|c|}
\hline symbol & tekst laciński & tekst polski \\
\hline $\mathrm{A}_{3}$ & $\begin{array}{l}\text { ut cordis nostri vas caelestis } \\
\text { gratiae impleas, } \\
\text { auro sapientiae effulgere } \\
\text { facias, } \\
\text { tuae virtutis potentia } \\
\text { consolides, } \\
\text { lapide virtutum pretioso } \\
\text { adornes; } \\
\text { oleum misericordiae tuae, } \\
\text { tu oliva benedicta, super nos } \\
\text { effundas, } \\
\text { quo peccatorum nostrorum } \\
\text { multitudinem operias; } \\
\text { qua ad caelestis gloriae altitu- } \\
\text { dinem sublevari et cum beatis } \\
\text { beatificari mereamur. }\end{array}$ & $\begin{array}{l}\text { abyś napełniła naczynie serca } \\
\text { naszego niebieską łaską, } \\
\text { abyś uczyniła nas } \\
\text { jaśniejącymi } \\
\text { złotem mądrości, } \\
\text { umocniła potęgą Twojej } \\
\text { mocy, } \\
\text { ozdobiła drogim kamieniem } \\
\text { cnót, wylała na nas olej miło- } \\
\text { sierdzia Twojego, } \\
\text { - Ty Oliwko Błogosławiona - } \\
\text { zakryła nim mnogość na- } \\
\text { szych grzechów } \\
\text { abyśmy zasłużyli na wy- } \\
\text { niesienie na wysokość } \\
\text { niebieskiej chwały i byli } \\
\text { szczęśliwymi ze świętymi. }\end{array}$ \\
\hline $\mathrm{B}_{1}$ & $\begin{array}{l}\text { Praestante Iesu Christo, } \\
\text { filio tuo, } \\
\text { qui te hodierna die super } \\
\text { choros angelorum exaltavit, } \\
\text { diademate regni coronavit } \\
\text { et in solio aeterni liminis } \\
\text { collocavit. }\end{array}$ & $\begin{array}{l}\text { Za sprawą Jezusa Chrystusa, } \\
\text { Syna Twego, } \\
\text { który Cię w dniu dzisiej- } \\
\text { szym ponad chóry aniołów } \\
\text { wyniósł, } \\
\text { diademem królestwa } \\
\text { ukoronował } \\
\text { i na tronie wiecznego progu } \\
\text { umieścił. }\end{array}$ \\
\hline $\mathrm{B}_{2}$ & $\begin{array}{l}\text { Cui est honor et gloria per } \\
\text { aeterna saecula. } \\
\text { Dicat omnis Ecclesia: } \\
\text { Amen. Alleluia. }\end{array}$ & $\begin{array}{l}\text { Któremu jest cześć i chwała } \\
\text { na wieki wieków. } \\
\text { A cały Kościół niech } \\
\text { odpowie: } \\
\text { Amen. Alleluja. }\end{array}$ \\
\hline
\end{tabular}


Slowa kluczowe: Antoni z Padwy, kazania, mariologia, modlitwy maryjne, franciszkanizm

Schlüsselworte: Antonius von Padua, Predigten, Mariologie, Mariengebete, Franziskanismus

\section{Mariengebete „Rogamus ergo te Domina nostra“ des HI. Antonius von Padua}

Zusammenfassung

Ein besonderer Teil der Sammlung von Predigten des Hl. Antonius umfasst einige Gebete. Sie sind ein Ausdruck der Frömmigkeit und des Wissens des ersten Theologielehrers im franziskanischen Orden. Diese kurzen Texte, die Krönung der jeweiligen Predigt, wurden von hl. Antonius entwickelt, um seine Zuhörer, sowie andere Prediger einzuladen, ihr ganzes Leben Gott und Maria anzuvertrauen. Sechs hier analysierte Mariengebete „Rogamus ergo te Domina nostra“ sind ein Zeugnis der einzigartigen Beziehung, die Antonius mit der Mutter des Herrn verbunden hat. Unser Heiliger entwickelt in ihnen seine originelle Vorstellung von Maria und ihrer Rolle im Leben Christi und seiner Kirche. Der Autor versucht die sprachlichen und theologischen Inhalte der Mariengebete zu analysieren, indem er auf die bemerkenswerte Konsequenz in gewählten Worten, Symbolen und Bildern betrachtet. Diese Analyse führt zur Darstellung der ausgewählten Gebete als Zeugnis der Frömmigkeit und der Theologie in den Anfängen des Franziskanerordens. 